\title{
Aerosol plume transport and transformation in high spectral resolution lidar measurements and WRF-Flexpart simulations during the MILAGRO Field Campaign
}

\author{
B. de Foy ${ }^{1}$, S. P. Burton ${ }^{2}$, R. A. Ferrare ${ }^{2}$, C. A. Hostetler ${ }^{2}$, J. W. Hair ${ }^{2}$, C. Wiedinmyer ${ }^{3}$, and L. T. Molina ${ }^{4,5}$ \\ ${ }^{1}$ Department of Earth and Atmospheric Sciences, Saint Louis University, MO, USA \\ ${ }^{2}$ NASA Langley Research Center, Hampton, VA, USA \\ ${ }^{3}$ National Center of Atmospheric Research, Boulder, CO, USA \\ ${ }^{4}$ Molina Center for Energy and the Environment, CA, USA \\ ${ }^{5}$ Department of Earth, Atmospheric and Planetary Sciences, Massachusetts Institute of Technology, MA, USA
}

Received: 5 October 2010 - Published in Atmos. Chem. Phys. Discuss.: 19 November 2010

Revised: 25 March 2011 - Accepted: 10 April 2011 - Published: 15 April 2011

\begin{abstract}
The Mexico City Metropolitan Area (MCMA) experiences high loadings of atmospheric aerosols from anthropogenic sources, biomass burning and wind-blown dust. This paper uses a combination of measurements and numerical simulations to identify different plumes affecting the basin and to characterize transformation inside the plumes. The High Spectral Resolution Lidar on board the NASA LaRC B-200 King Air aircraft measured extinction coefficients and extinction to backscatter ratio at $532 \mathrm{~nm}$, and backscatter coefficients and depolarization ratios at 532 and $1064 \mathrm{~nm}$. These can be used to identify aerosol types. The measurement curtains are compared with particle trajectory simulations using WRF-Flexpart for different source groups. The good correspondence between measurements and simulations suggests that the aerosol transport is sufficiently well characterized by the models to estimate aerosol types and ages. Plumes in the basin undergo complex transport, and are frequently mixed together. Urban aerosols are readily identifiable by their low depolarization ratios and high lidar ratios, and dust by the opposite properties. Fresh biomass burning plumes have very low depolarization ratios which increase rapidly with age. This rapid transformation is consistent with the presence of atmospheric tar balls in the fresh plumes.
\end{abstract}

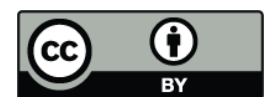

Correspondence to: B. de Foy (bdefoy@slu.edu)

\section{Introduction}

With maximum hourly concentrations above $300 \mu \mathrm{g} / \mathrm{m}^{3}$ for $\mathrm{PM}_{2.5}$ and above $600 \mu \mathrm{g} / \mathrm{m}^{3}$ for $\mathrm{PM}_{10}$ during the MILAGRO field campaign, the Mexico City Metropolitan Area (MCMA) experiences particularly high aerosol loadings (de Foy et al., 2008). These contribute to high exposure levels on longer time scales which are an important health concern (Molina and Molina, 2002). These aerosols are the result of emissions from very different sources including urban emissions, biomass burning smoke and wind suspended dust (Salcedo et al., 2006; Raga et al., 2001). The aerosol plumes are transported by complex wind patterns in the basin leading to inhomogeneous plume dispersion (Fast and Zhong, 1998) that is strongly impacted by local convergence zones (Jazcilevich et al., 2005; de Foy et al., 2006a. Intense vertical mixing in the afternoon leads to rapid venting of the urban plume outside of the basin (de Foy et al., 2006c). This paper focuses on identifying aerosol plumes in the MCMA basin during the MILAGRO field campaign using High Spectral Resolution Lidar (HSRL) measurements (Hair et al., 2008) and WRF-Flexpart particle trajectory simulations of known sources (de Foy et al., 2009b).

MILAGRO (Megacity Initiative: Local And Global Research Observations) was an international field campaign in March 2006 that brought together hundreds of scientists. The goal was to study processes affecting atmospheric chemistry from the urban to the regional scale using the MCMA as a case study (Molina et al., 2010). Nested within this field campaign was MCMA-2006 studying urban emissions

Published by Copernicus Publications on behalf of the European Geosciences Union. 
and pollution within the basin, MAX-MEX studying aerosol transport and transformation in the urban plume leaving the basin, MIRAGE-Mex studying the pollution on the regional scale and INTEX-B studying large-scale impacts of pollution export (Molina et al., 2010). The lidar measurements used in this study are part of MAX-MEX and INTEX-B, and the focus of the study is on the MCMA basin.

\subsection{Aerosol composition}

Aerosol composition at ground level in the MCMA was found to consist of roughly one quarter dust, one quarter secondary inorganic aerosols and one half organic matter for $\mathrm{PM}_{10}$, with similar patterns for $\mathrm{PM}_{2.5}$ (Querol et al., 2008). Transmission Electron Microscope (TEM) analysis found that most particles were coated or consisted of aggregates (Adachi and Buseck, 2008). Over half of those particles consisted of soot (black carbon) coated with organic matter and sulfates. This is consistent with Aiken et al. (2009) who found that half of the aerosols consisted of Secondary Organic Aerosol (SOA) and that the rest were split between primary urban emissions and biomass burning organic aerosols. Likewise, Stone et al. (2008) used a Chemical Mass Balance model to identify sources of ambient organic carbon and found that motor vehicles accounted for half of the urban organic carbon and that impacts of biomass burning varied from 5 to $26 \%$.

On the regional scale, Yokelson et al. (2007), Crounse et al. (2009), and Yokelson et al. (2011) found that biomass burning emissions could cause more than half of the organic aerosol mass in the plumes sampled by aircraft outside the basin and at higher altitudes. In addition, Christian et al. (2010) identified significant aerosol sources due to biofuel use and garbage burning throughout the region. These regional sources led to surface impacts in the MCMA, although they remained smaller than the impacts from local sources (Aiken et al., 2010).

\subsection{Aerosol transformation}

The picture that arises of aerosols in the MCMA plume is one of a complex mixture of aerosols from very different sources. In addition, the plume is highly reactive and leads to considerable formation of SOA. As the plume oxidizes, both the physical and optical properties evolve over a short time scale in a way that can be accounted for using bulk aerosol categories rather than detailed chemical composition (Jimenez et al., 2009). For the MCMA, rapid SOA formation was measured during the first day of plume transport. After that, total amounts of SOA did not increase even though oxidation continued transforming the plume (DeCarlo et al., 2010). For plumes with high biomass burning content it was further shown that aging and transformation could add nearly half of the equivalent mass of the original primary organic aerosol (DeCarlo et al., 2010).
A detailed chemical analysis on the level of individual particles confirms the importance of SOA by identifying that the most prevalent aerosol type contains mixed inorganic species coated in organic material (Moffet et al., 2010). Furthermore, the fraction of organic material increases with transport away from the MCMA. Fresh aerosols from the MCMA were found to have lower specific absorption which increased with distance travelled (Doran et al., 2007), although the relationship was weak and aerosol coating took place during the day but not at night (Doran et al., 2008). Similar results from aircraft measurements above the basin and the near-field outflow sites also found an increase in organic aerosols (Kleinman et al., 2008). Analysis of the size distribution revealed that the increase in aerosol concentrations does not come from larger particles but rather from an increase in the number of particles in the accumulation mode (Kleinman et al., 2009). This was found to correspond to an increase in particles in the ultra-fine and Aitken mode with photochemical age.

Studies of biomass burning plumes not limited to the MCMA or to MILAGRO have found that they have a large range of optical properties depending on the type of fire and the age of the plume (Reid et al., 2005). Janhäll et al. (2010) analyzed the geometric mean diameter and geometric standard deviation for fresh (less than $1 \mathrm{~h}$ old) and aged smoke and found that the fresh smoke had much smaller particles with a broader distribution of sizes. These small particles in the nucleation mode transfer to the accumulation mode within half an hour, but Janhäll et al. (2010) suggest that they have little influence on optical properties.

Yokelson et al. (2009) identified tar balls during MILAGRO using TEM in plume samples 10 to $30 \mathrm{~min}$ old, but not in the fresh sample that was collected within a few minutes of emissions. Atmospheric tar balls, not to be confused with blobs of oil in the ocean, are spherical particles that likely form within minutes from gas-to-particle conversion in the plume, and are particularly abundant in the initial hours of transformation (Posfai et al., 2004). They typically have diameters between 30 and $500 \mathrm{~nm}$ and consist mainly of carbon and oxygen. They efficiently scatter and absorb light which makes them important in terms of regional haze and climate forcing (Hand et al., 2005). There is conflicting evidence of hygroscopicity, but it seems that aging and oxidation leads to particle coating and enhanced solubility (Semeniuk et al., 2007). They have been called "brown carbon" because of their complex refractive indices and, in addition to young biomass burning plumes, have also been found in East-Asian outflow air masses (Alexander et al., 2008; Posfai and Buseck, 2010). Laboratory studies have further examined their morphology (Chakrabarty et al., 2006) and suggest that they may have a significant impact on the earth's radiation budget (Chakrabarty et al., 2010). 


\subsection{Plume transport}

Fast et al. (2007) describes the general meteorological conditions during MILAGRO along with the measurements available. Wind patterns were found to be representative of the climatological average for Mexico City (de Foy et al., 2008) and include similar transport scenarios to the previous campaign, MCMA-2003 (de Foy et al., 2005), (Molina et al., 2007). The formation of convergence lines and very high mixing heights are important meteorological features in the basin that lead to rapid venting of the plume and export into the free troposphere. During MILAGRO, maximum daytime boundary layer heights always reached $2000 \mathrm{~m}$ above ground level and frequently exceeded $4000 \mathrm{~m}$ (Shaw et al., 2007). $\mathrm{SO}_{2}$ was used as a tracer to identify vertical stratification of distinct plumes during the campaign (de Foy et al., 2009a). This showed that at night a low level industrial plume frequently led to high concentrations of $\mathrm{SO}_{2}$ in the MCMA in combination with drainage flows around the basin slopes. The elevated plume from the Popocatepetl volcano, located on the southeastern edge of the basin, only mixed down to the surface under certain occasions during the day but otherwise was transported aloft above the surface. This combination of daytime basin mixing and longer range transport stratified in the vertical can lead to a plug flow with segmented plumes travelling very rapidly at high altitude but much slower nearer the surface (Voss et al., 2010).

Lewandowski et al. (2010) performed an urban transect of the MCMA with a mobile lidar. They observed directly the residual layers aloft, the mixed layer below growing during the day until it mixes with the residual layer, and the transport through the gap in the southeast of the basin. The valley to the south is at a lower elevation than the basin so that as the gap flow moves south, the MCMA plume continues at a constant height and is separated from the surface flow. The vertical stratification persists over the whole region and was detected by aircraft measurements a couple of hundred kilometers to the east (DeCarlo et al., 2008).

The NASA Langley airborne HSRL was flown on board the NASA LaRC B-200 King Air aircraft, and acquired detailed high resolution profiles of aerosol extinction, optical depth, backscatter and depolarization during MILAGRO. The measurements are described in Sect. 2 and the Lagrangian particle simulations in Sect. 3. Simulations of urban, biomass burning and dust source types enables the identification of individual plumes in the data as well as an estimation of their ages. Section 4 presents the results for biomass burning plumes and dust plumes, and then for urban transects in the MCMA and for flights following the plume as it is transported outside the basin. Section 5 discusses the relevance of the results to aerosol transport and transformation as well as for the evaluation of numerical simulations.

\section{High spectral resolution lidar}

The High Spectral Resolution Lidar technique was developed to separate the aerosol backscatter from molecular backscatter and therefore estimate aerosol extinction and backscatter coefficients independently (Shipley et al., 1983). This enables the direct measurement of the lidar ratio, which is the ratio of extinction to backscatter and provides an additional parameter for discriminating among aerosol types (Hair et al., 2008). The HSRL has been used to evaluate combined active and passive aerosol extinction profiles from satellite, and is being developed for space observation (Burton et al., 2010).

The National Aeronautics and Space Administration (NASA) Langley Research Center (LaRC) airborne High Spectral Resolution Lidar (HSRL) used during MILAGRO is described in detail in Hair et al. (2008). The lidar uses a pulsed Nd:YAG laser with output at $532 \mathrm{~nm}$ and $1064 \mathrm{~nm}$. An iodine vapor filter is used to discriminate between the Mie scattering of the aerosols and the Cabannes-Brillouin molecular scattering at the $532 \mathrm{~nm}$ wavelength. This provides independent measurements of aerosol backscatter and extinction coefficients. At $1064 \mathrm{~nm}$, the standard backscatter lidar technique is used to provide aerosol backscatter coefficients. In addition, the degree of linear polarization is measured at both wavelengths. Radiometric calibration of the $532 \mathrm{~nm}$ channels is performed internally thereby eliminating the need to calibrate against atmospheric targets for which the aerosol loading is uncertain. The $1064 \mathrm{~nm}$ backscatter retrieval does rely on calibration to a region of low aerosol loading in the profile, but benefits from an estimate of the aerosol backscatter from the internally calibrated $532 \mathrm{~nm}$ channels.

Rogers et al. (2009) describe the evaluation of the HSRL during MILAGRO. The aerosol measurements were compared with in situ aerosol scattering and absorption measurements on board the C-130, G-1 and J-31 aircraft as well as ground based measurements from the Aerosol Robotic Network (AERONET). Bias in extinction coefficients at $532 \mathrm{~nm}$ were found to be below $3 \%$, and root mean square differences below $50 \%$.

Four intensive parameters that depend only on the aerosol type and not on the concentration can be calculated from the measurements: the lidar ratio, the aerosol depolarization ratio at $532 \mathrm{~nm}$ and $1064 \mathrm{~nm}$, and the backscatter coefficient color ratio. The latter is defined as the backscatter at $532 \mathrm{~nm}$ divided by the backscatter at $1064 \mathrm{~nm}$. For the analysis, instead of using two depolarization ratios, we use the aerosol depolarization ratio at $532 \mathrm{~nm}$ and the depolarization color ratio defined as the aerosol depolarization ratio at $1064 \mathrm{~nm}$ divided by that at $532 \mathrm{~nm}$.

The lidar ratio has vertical resolution of $300 \mathrm{~m}$ and temporal resolution of $1 \mathrm{~min}$ (corresponding to $6 \mathrm{~km}$ horizontal resolution) whereas the depolarization ratio and backscatter coefficients have a vertical resolution of $60 \mathrm{~m}$ and temporal 
Table 1. HSRL optical properties by aerosol types, along with the significance of high and low values for each property, see text for discussion (BB = Biomass Burning).

\begin{tabular}{llllll}
\hline Aerosol Type & $532 \mathrm{~nm}$ Depolarization & Dep. Color Ratio & Bsc. Color Ratio & Lidar Ratio & Example \\
\hline Fresh BB & Very Low & Low & High & Varies & Fig. 5 \\
Fresh BB Mix & Low & High & Medium High & Varies & Fig. 4 \\
Urban & Low & Medium & Medium & High & Fig. 8 (red ellipse) \\
Dust & High & Medium Low & Low & Medium Low & Fig. 6 \\
Mixed & High & Medium & Low & Varies & Fig. 11 (green ellipses) \\
\hline Significance & & & & \\
Lower & Spherical & Smaller Non-spherical & Larger & Less Absorbing & \\
Higher & Non-spherical & Larger Non-spherical & Smaller & More Absorbing & \\
\hline
\end{tabular}

resolution of $10 \mathrm{~s}$ (corresponding to $1 \mathrm{~km}$ horizontal resolution).

The depolarization ratio discriminates between spherical and non-spherical particles. The lidar ratio helps identify pollution which tends to be more absorbing, and hence have a higher ratio (Müller et al., 2007). The backscatter color ratio is inversely related to aerosol size and identifies the smaller aerosols associated with smoke and urban pollution (Sasano and Browell, 1989). Finally, the depolarization color ratio has been less studied, but can provide information about the relative size of the non-spherical particles and may also provide some discrimination between smoke and pollution (Sugimoto and Lee, 2006; Ferrare et al., 2011).

Cattrall et al. (2005) used a clustering algorithm to classify aerosols into source types based on the intensive optical properties. This has been further developed to classify aerosol types encountered during 10 field campaigns all over North America (Ferrare et al., 2011). The HSRL typing analysis has been valuable for identifying smoke aerosols during the ARCTAS mission (Warneke et al., 2010) and urban aerosols during the MILAGRO mission (Molina et al., 2010).

Table 1 provides an overview of the aerosol optical properties used in the discussion based on both prior and current lidar measurement studies. This summarizes information about different aerosol types and identifies examples in the measurements.

The HSRL operated on 20 research flights during MILAGRO including the arriving and departing flights. This paper focuses on the 10 flights between 3 March and 15 March. This period corresponds to the drier part of the campaign with fewer clouds, better data availability and more biomass burning and wind-blown dust.

\section{Modeling}

Numerical simulations were used to study aerosol transport with a focus on identifying source regions and particle ages. For this purpose, we use a Lagrangian model which tracks particle trajectories in both forward and backward mode using high resolution wind simulations.

The meteorological simulations used in this study are described and evaluated in detail in de Foy et al. (2009b) and are the same as the ones used in the study of $\mathrm{SO}_{2}$ transport in the basin described in de Foy et al. (2009a). The model was evaluated by three different methods. First, statistical performance metrics were calculated using both surface observations and vertical profiles of temperature, humidity, wind speed and wind direction. Second, the model representation of wind clusters identified from the data was compared for both surface wind patterns and radiosonde synoptic patterns. Third, the model was evaluated by comparing results from "Concentration Field Analysis". This evaluates the model by seeing if trajectories based on the simulated wind fields are able to identify correctly known emissions of air pollutants based on surface measurements at different fixed sites.

Mesoscale meteorological simulations were carried out with the Weather Research and Forecast model version 3.0.1 (WRF, Skamarock et al., 2005) using the Global Forecast System (GFS) as initial and boundary conditions. There were three domains in the simulation with grid resolutions of 27,9 and $3 \mathrm{~km}, 41$ vertical levels and one-way nesting. Diffusion in coordinate space was used for domains 1 and 2, and in physical space for domain 3 (Zängl et al., 2004). The following options were used: the Yonsei University (YSU) boundary layer scheme (Hong et al., 2006), the KainFritsch convective parametrization (Kain, 2004), the WSM6 microphysics scheme, the Dudhia shortwave scheme and the RRTM longwave scheme. High resolution satellite remote sensing was used to improve the land surface representation in the NOAH land surface model for domains 2 and 3 by using landuse, surface albedo, vegetation fraction and land surface temperature from the Moderate Resolution Imaging Spectroradiometer (MODIS) as described in de Foy et al. (2006b).

Stochastic particle trajectories were calculated with FLEXPART (Stohl et al., 2005) using WRF-FLEXPART (Fast and Easter, 2006; Doran et al., 2008). Vertical diffusion coefficients were calculated based on the mixing heights and 

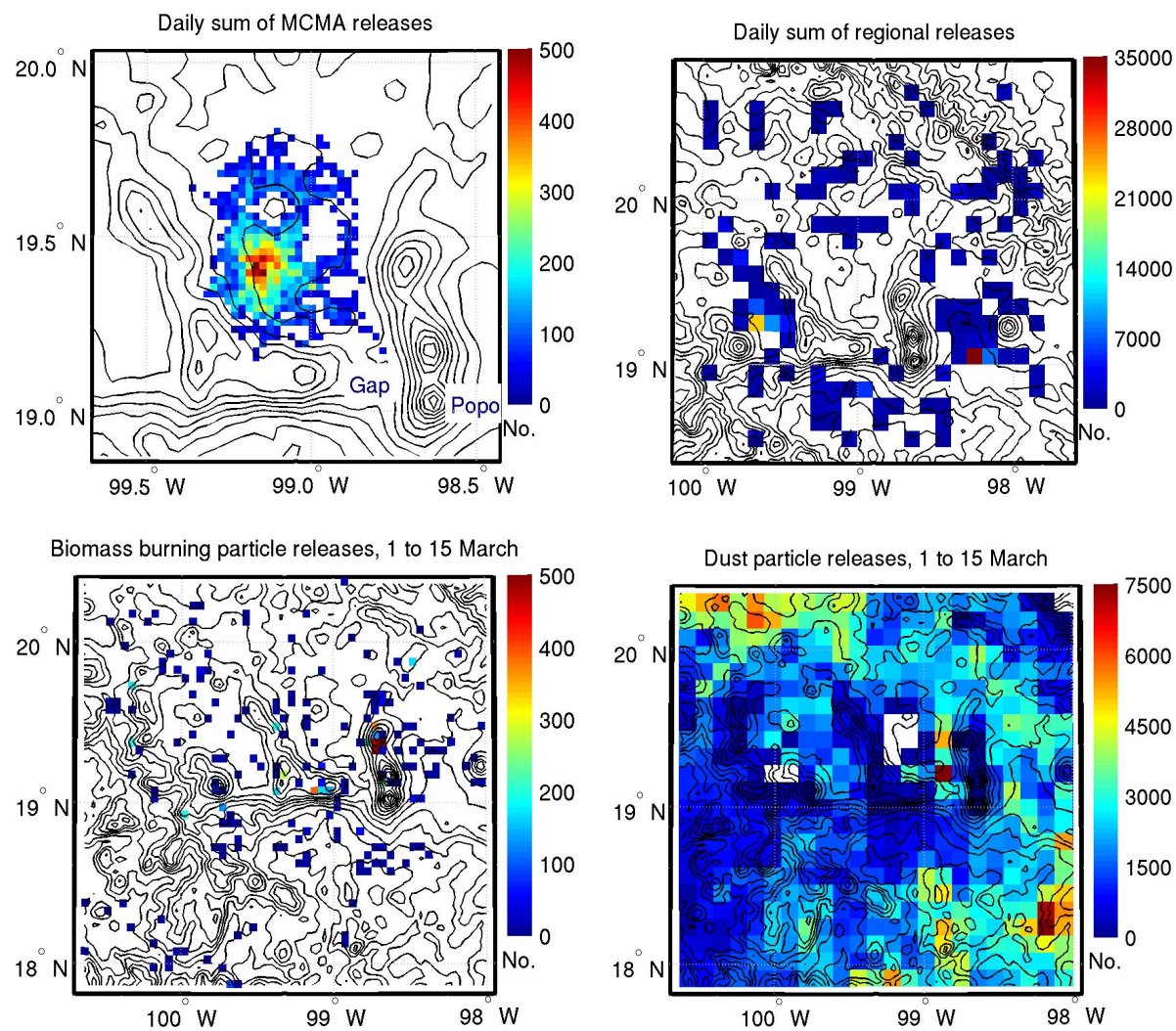

Fig. 1. Maps of particles released for urban and regional emissions (daily sum) and biomass burning and dust emissions (sum from 1 to 15 March). Terrain contour lines shown every $250 \mathrm{~m}$. Basin map also shows the location of the mountain gap and the Popocatepetl volcano discussed in text.

surface friction velocity from the mesoscale models. Subgrid scale terrain effects were turned off and a reflection boundary condition was used at the surface to eliminate all deposition effects. Particle locations were saved every hour for analysis.

Separate particle simulations were carried out as tracers for urban MCMA emissions, urban emissions in the region surrounding the MCMA, biomass burning emissions and wind-blown dust emissions. Forward trajectories were calculated for every hour of the field campaign with trajectories integrated for $48 \mathrm{~h}$. Figure 1 shows the resulting grid of the daily sum of particle releases for each group. Figure 2 shows the hourly profile of the number of particles released for both the urban and the regional emissions used for each day, and the hourly variation of biomass burning and dust used for 1 to 15 March.

For the urban plume, forward trajectories were calculated using urban CO emissions. These were based on the 2006 official emissions inventory for the MCMA (Secretaría del Medio Ambiente del Gobierno del Distrito Federal, 2008). $\mathrm{CO}$ emissions are mainly from mobile sources. Gridded emissions were therefore obtained by projecting fine scale road infrastructure network maps of the city onto a $2.25 \mathrm{~km}$ grid. This was combined with updated data of vehicle counts and diurnal profiles (Lei et al., 2007; Song et al., 2010). The grids were scaled to have a daily average of 2000 particles per hour released in the bottom $50 \mathrm{~m}$ of the boundary layer.

Anthropogenic emissions in the regions surrounding the MCMA were based on Mena-Carrasco et al. (2009) who used a number of sources. The bulk of the particles released are due to the urban centers of Puebla to the east and Toluca to the west, with smaller contributions from Cuernavaca to the south and Pachuca to the northeast. For some of the plots and analysis, merged particle fields were created by scaling the regional emissions to the MCMA values and obtaining a single urban emissions field.

Tracers of biomass burning emissions were based on daily emission estimates of $\mathrm{CO}$ calculated using the Fire INventory from NCAR (FINN) version 1, an emission framework method described in Wiedinmyer et al. (2006) and Wiedinmyer et al. (2010). Fire counts (MODIS Data Processing System) were provided by the University of Maryland, see MODIS Rapid Response project (2002) and Giglio et al. (2003). To account for the inconsistent daily coverage of the MODIS data in the tropical latitudes, fire detections in these equatorial regions are counted for a 2-day period, following 

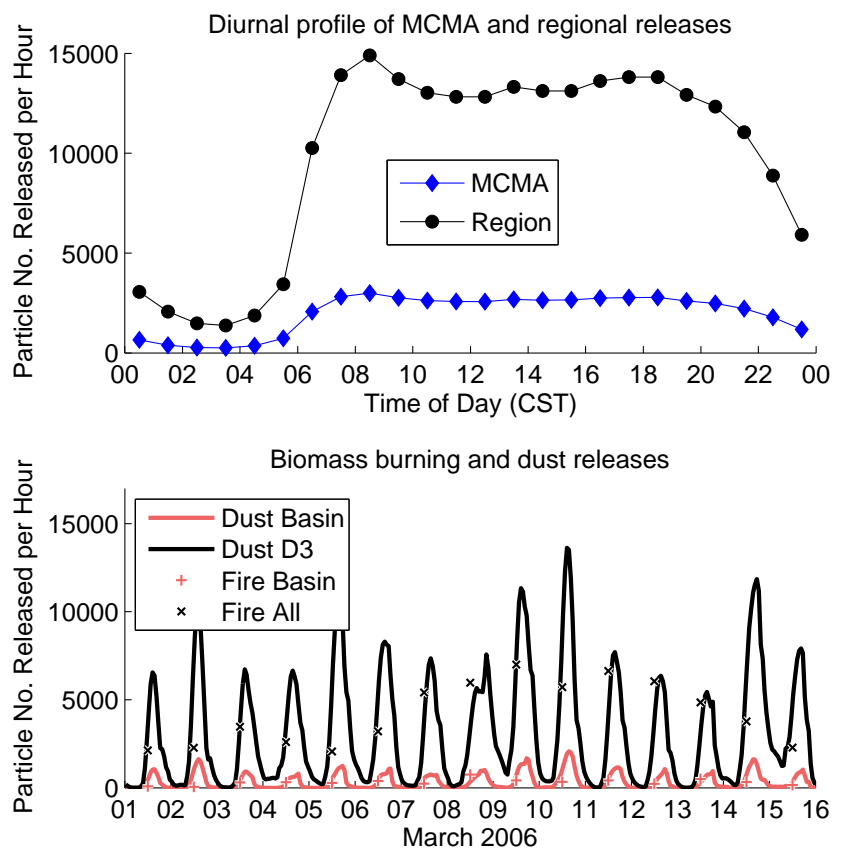

Fig. 2. Top: hourly profile of number of particles released for MCMA and regional emissions. Bottom: hourly emissions of dust and biomass burning smoke for 1-15 March 2006. For biomass, the value for each day is used from 8am until 8am the following day. D3 means WRF domain 3, see Fig. 1d.

similar methods described by Al-Saadi et al. (2008). Land cover was determined with the MODIS Land Cover Type product (Friedl et al., 2010) and fuel loadings from Hoelzemann et al. (2004) and Akagi et al. (2010). Emission factors were taken from multiple sources (e.g., Andreae and Merlet, 2001; M. O. Andreae, personal communications, 2008; Akagi et al., 2010).

The emissions are a revised version of the ones used in Aiken et al. (2010) and DeCarlo et al. (2010). Daily emissions totals are divided into hourly emissions starting at 8 a.m. of the current day until 8am the following day. This is to account for smoldering emissions that continue during the night, and for the fact that many of the fires are agricultural fires that are started in the morning. Note that simulating particle releases every hour makes sense because we are interested in detecting individual events. This is in contrast to Aiken et al. (2010) where a diurnal profile of emissions was used because we were analyzing hourly impacts at a fixed site.

Tracers of dust emissions were calculated using the DUSTRAN dust transport module (Shaw et al., 2008) based on the WRF simulations. This parametrization is based on the friction velocity in the model and takes into account the land use type, soil type, vegetation fraction and soil moisture in estimating particulate mass loadings. We assumed mediumfine soils corresponding to clay-loam for the MCMA. Values of emissions in units of $\mathrm{g} / \mathrm{m}^{2} \mathrm{~s}$ were converted to number of particles with a proportionality constant, and emissions were grouped into a single area release for each two by two group of grid cells in order to reduce computational load. The focus of this paper is on the pattern of the emissions and the plume transport and so we shall not evaluate the quantities of dust emitted, but it is worth noting in passing that the DUSTRAN emissions are several orders of magnitude larger than the wind-blown dust estimates in the official MCMA inventory. Aerosol data suggests that the MCMA inventory is underestimated (Querol et al., 2008). The MCMA modeling studies suggest that the DUSTRAN emissions may be too high (Qian et al., 2010). Using an alternative model, Hodzic et al. (2009) found that wind-blown dust could account for $10 \%$ to $70 \%$ of $\mathrm{PM}_{2.5}$ depending on meteorological conditions. The estimates derived from DUSTRAN are consistent with this and suggest the ubiquitous presence of airborne dust in the region for the time period modeled. Karydis et al. (2010) describe results using an alternative formulation for dust emissions and Watson and Chow (2000) provide further discussion of the uncertainties in the inventories.

Overall, there are urban and regional $\mathrm{CO}$ emissions, biomass burning emissions from FINN, and dust emissions from DUSTRAN. The Flexpart simulations were used to identify the particle type as "Urban", "Fire", "Dust", or any combination of those three for cells corresponding to each HSRL data point. For each emissions source, particles were counted inside grid cells corresponding to HSRL measurements. The particle fraction was obtained by scaling the number of numerical particles released from each source to equivalent $\mathrm{CO}$ emissions. This was chosen because the anthropogenic CO inventory is relatively well constrained and has been found to provide good quantitative agreement with measurements (de Foy et al., 2007; Fast et al., 2009). For biomass burning, a ratio of 1 to 10 for $\mathrm{PM}_{2.5}$ to $\mathrm{CO}$ was used to convert to equivalent $\mathrm{CO}$ emissions. Dust emissions pose a triple problem because there are greater uncertainties in their emissions, because they do not have corresponding $\mathrm{CO}$ emissions, and because they are so ubiquitous that they swamp the presence of other particle types. As a practical expedient, it was therefore decided to scale them as if the total $\mathrm{PM}_{2.5}$ mass of dust was similar to the biomass burning emissions. From there, the same ratio of 1 to 10 for $\mathrm{PM}_{2.5}$ to $\mathrm{CO}$ was applied. The cells were classified as being of a single aerosol type if that type accounted for more than two thirds of the scaled particle count. They were classified as a mix of all three (urban, biomass burning and dust) if each type accounted for less than $40 \%$. By adopting this method, we were able to identify areas that contained more urban or fire emissions than others, although it should be kept in mind that in practice, dust was present to some degree everywhere. Because Flexpart tracks individual particles, we subsequently calculated the mean age of the particles present in each grid cell based on the scaled particle counts. 


\section{Results}

\subsection{Biomass burning plumes}

The HSRL measured numerous biomass burning plumes during the first half of the field campaign. Figure $3 a$ and $b$ show maps of two flight segments that sampled biomass burning plumes, with corresponding curtain plots shown in Figs. 4 and 5. These were selected because the plumes have clear optical properties even though the simulations suffer from weak comparisons. Furthermore, they illustrate two contrasting types of optical properties. Twenty examples of biomass burning plumes sampled during the campaign are shown in the supplementary material, some of which are discussed in Sects. 4.3 and 4.4. Ellipses have been added to the curtain plots to relate features in the figures to the discussion in the text, as well as to facilitate visual comparison across the curtain plots. These are used to identify features of interest in the HSRL properties, and to highlight the corresponding simulation results.

On 7 March, the HSRL flew a leg south of the basin, moving northeastward towards the slopes of the Popocatepetl volcano as shown in Fig. 3a. The yellow ellipse on the left in Fig. 4 shows a smaller biomass burning plume in the valley to the south of the MCMA that is contained within the first $1000 \mathrm{~m}$ above ground level. The yellow ellipse to the right shows a bigger biomass burning plume on the eastern slope of the volcano, that extends more than $2000 \mathrm{~m}$ above ground level. The green ellipse in the middle identifies a large plume of mixed aerosols south of the basin gap, between 3000 and $4500 \mathrm{~m}$ m.s.l.

The Flexpart simulations of biomass burning do not show many particles for the small plume on the left. However, Fig. 3a shows that there was a fire just northwest of the flight leg. For the larger plume to the right, there is a weak signal of a fire plume in the simulations, barely seen as light blue on the navy background. The emissions model identified a small fire just south of the flight curtain (see Fig. 3a). In both cases, it is possible that the emissions estimates were too low for these fires and also that discrepancies in the transport direction were sufficient for the model to miss the bulk of the plume. In the middle of the figure, shown by the green ellipse, is a mixed plume of dust, biomass burning and urban aerosols. This plume came from the MCMA basin through the mountain gap and was then transported as an elevated layer separated from the surface flow. In the simulations, the plume can be seen to be at the surface, below the green ellipse, because Flexpart transported it along terrain contours rather than at constant elevation. The separation of the flow passing over the basin rim will be discussed further in Sect. 4.3.

The biggest difference in optical properties between the aerosols in the biomass burning plumes and the rest is the low aerosol depolarization ratio at $532 \mathrm{~nm}$ which is between 0.05 and 0.1 , in contrast with regional values between 0.1 and
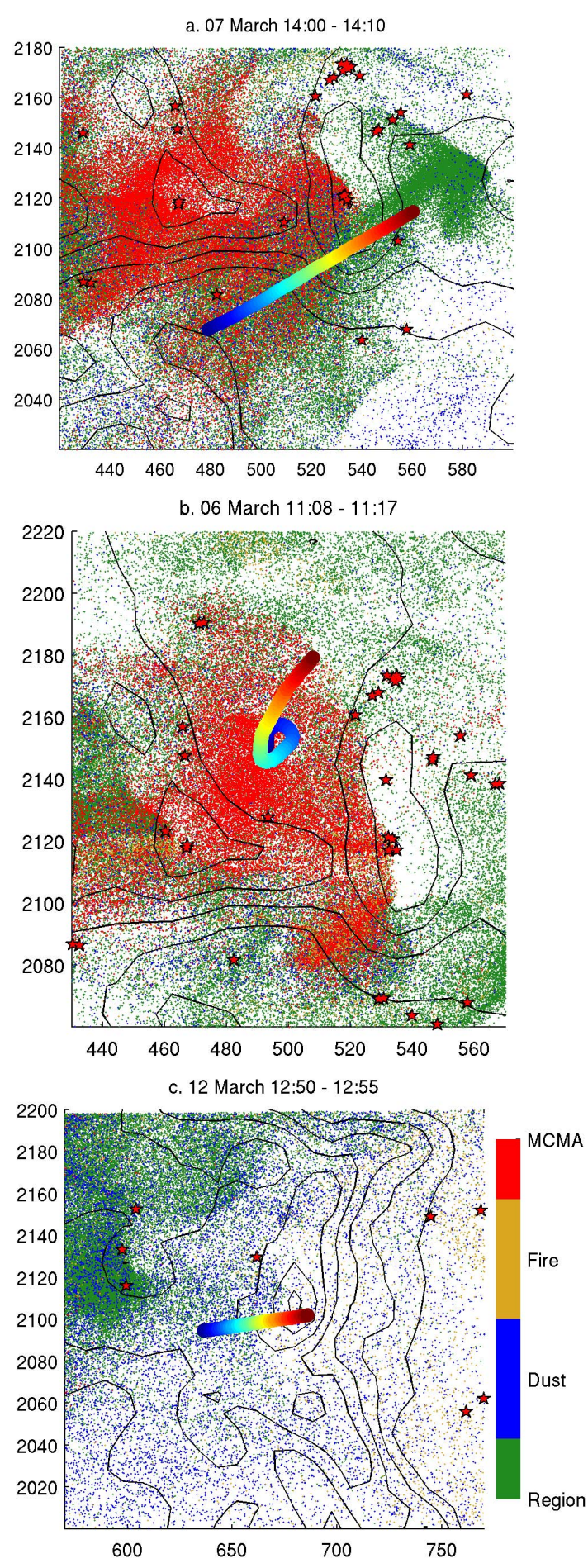

Fig. 3. Flexpart particle clouds colored by emission source using the colorbar in (c). The path of the HSRL curtain plots is shown by the colored line. The corresponding profile can be found by matching the color along the flight path with the colorbar across the top of the curtain plots. (a) corresponds to Fig. 4, (b) to Fig. 5 and (c) to Fig. 6. Stars indicate burning fires. Axes show Universal Transverse Mercator zone 14 coordinates in kilometers. Terrain contours shown every $500 \mathrm{~m}$. 


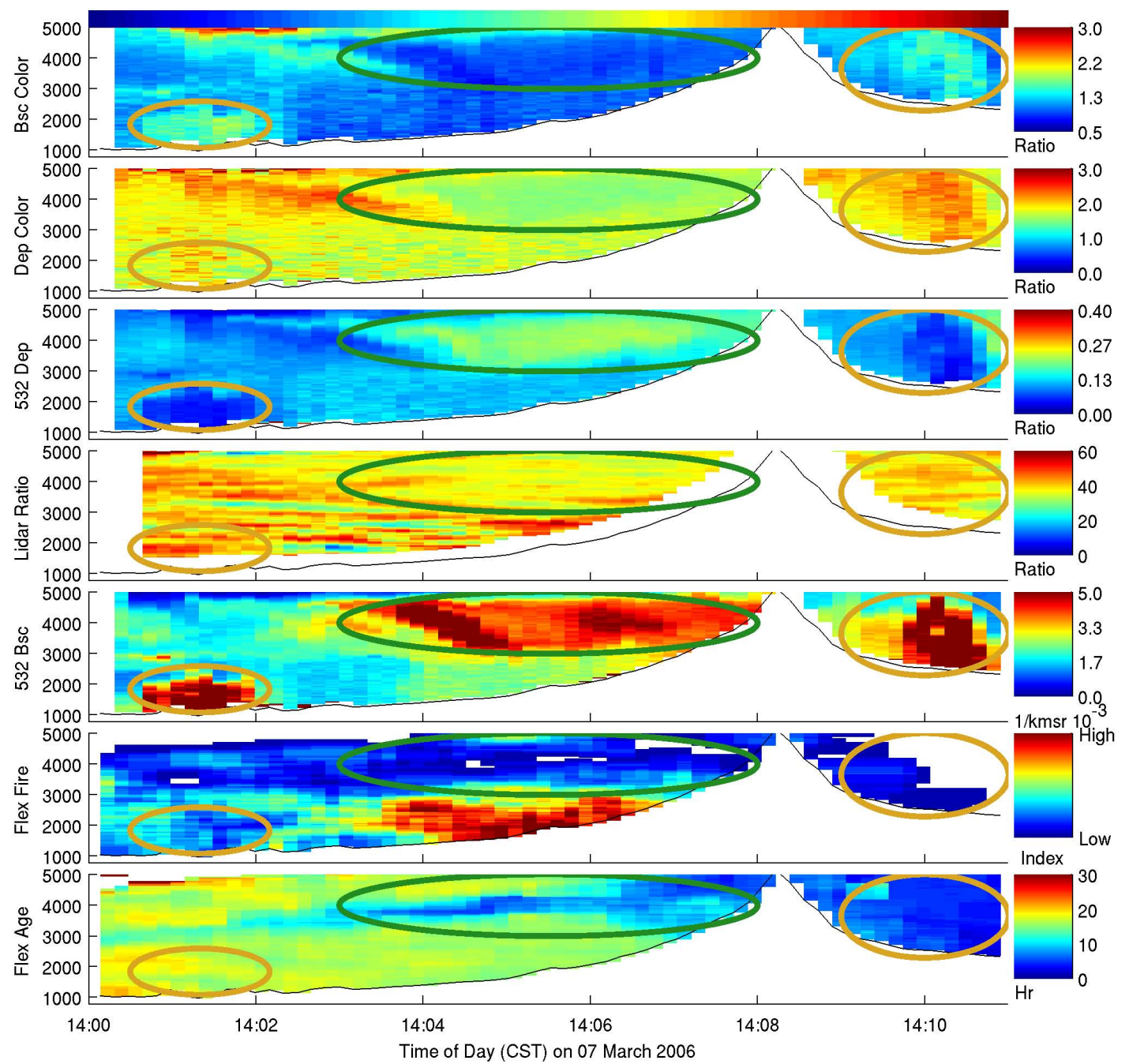

Fig. 4. Curtain plots of HSRL backscatter coefficients and intensive properties on 7 March 14:00 to 14:11 along with Flexpart mean age and particle count index for biomass burning tracers. Yellow ellipses show two fresh biomass burning plumes and the green ellipse shows the mixed urban plume transported by the gap flow. The y-axis is height above mean sea level. The location of the profile can be identified by matching the colorbar across the top with the flight paths shown in Fig. 3a.

0.2. The high backscatter color ratio gives a clear signal of the plumes with values around 2 compared with 1 to 1.5 elsewhere. The high depolarization color ratio stands out more clearly for the bigger plume with values up to 2.5 compared to values from 1.5 to 2 for the background and the smaller plume. The lidar ratio is not very different from the surrounding areas, with values between 30 and 60 .

On 6 March, the HSRL performed a loop over the MCMA and detected an elevated biomass burning plume transported above the surface urban layer. Figure $3 \mathrm{~b}$ shows the flight trajectory and the fire locations and Fig. 5 shows the curtain plots for this event. The yellow ellipses in the HSRL curtain plots highlight the two passes of the HSRL over the same plume. The Flexpart trajectories are in good agreement with the plumes showing that this is biomass burning smoke transported from a series of fires $20 \mathrm{~km}$ to the east. The average ages of the particles show that these are fresh plumes that are less than 2 or $3 \mathrm{~h}$ old. As seen above for the case on $7 \mathrm{March}$, the aerosol depolarization ratio at $532 \mathrm{~nm}$ of the smoke is much lower than the surrounding areas. In contrast with the 7 March case however, the backscatter color ratio is higher with values up to 3 and the depolarization color ratio is lower with values below 1 for the higher parts of the plume.

\subsection{Dust}

Dust was ubiquitous during MILAGRO, especially during the first half of the campaign which was very dry (Fast et al., 2007). Figure 6 shows the largest dust plume in the data which was on the flanks of Pico de Orizaba, a dormant volcano $200 \mathrm{~km}$ to the east of the MCMA, as shown in Fig. 3c. The high backscatter coefficients can be seen to 


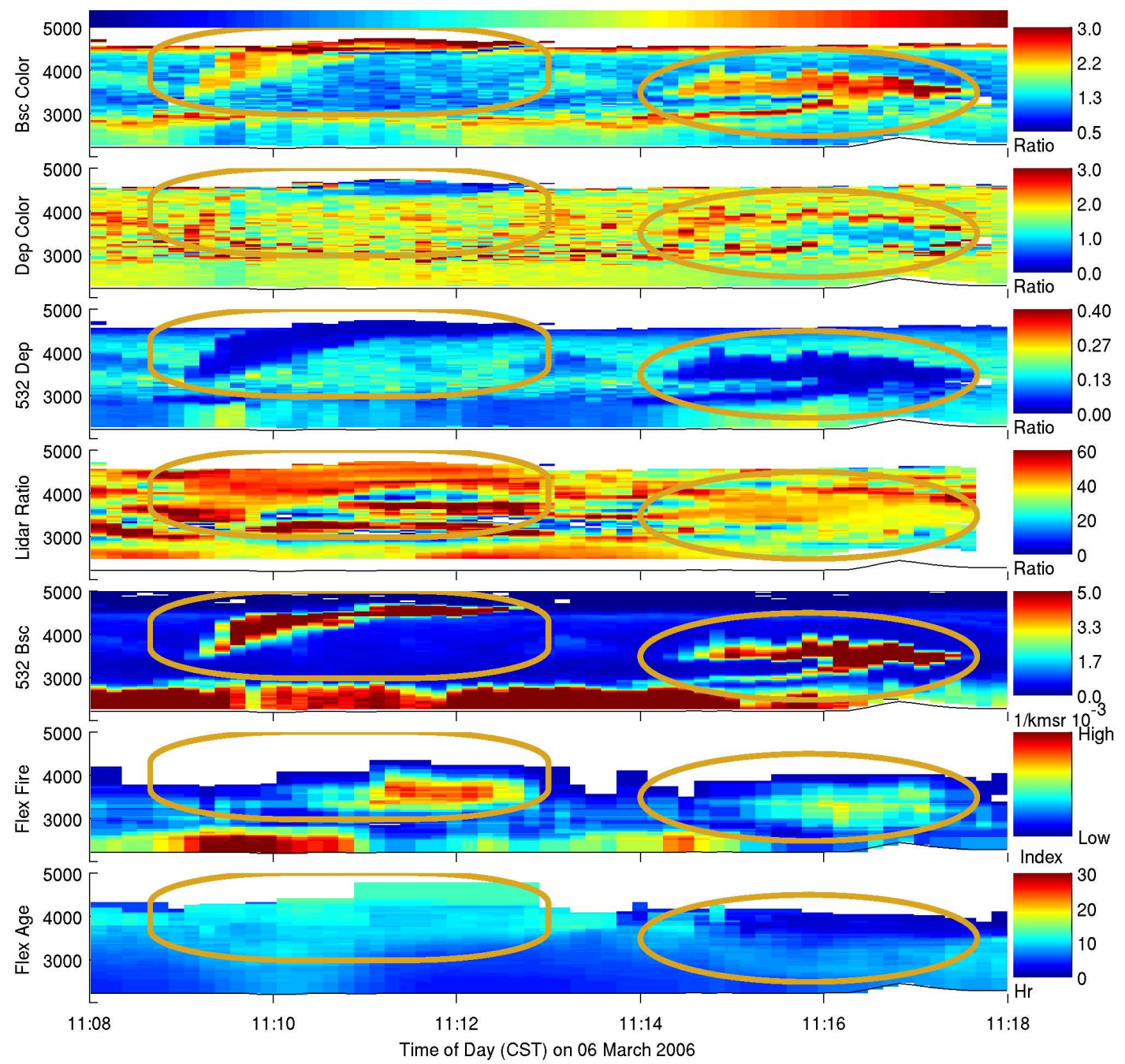

Fig. 5. Curtain plots of HSRL backscatter coefficients and intensive properties on 6 March 11:08 to 11:18 along with Flexpart mean age and particle count index for biomass burning tracers. Yellow ellipses show a fresh biomass burning plumes above the MCMA. The y-axis is height above mean sea level. The colorbar across the top corresponds to the trajectory shown in Fig. $3 b$.

extend upwards to the top of the mixed layer. These are associated with some of the highest values of aerosol depolarization ratios at $532 \mathrm{~nm}$, in the range of 0.25 to 0.35 . The depolarization color ratio is around 1 , at the low end of measurements, and the backscatter color ratio is also low with values ranging from 0.4 to 0.6 (in contrast with values up to 3 for biomass burning plumes). The high aerosol depolarization ratios extend in a tail towards the west suggesting that there was some transport aloft, but the low backscatter coefficients corresponding to this tail suggest that most of the dust has settled back to lower altitudes.

This transect is outside the fine domain for the WRF simulations. The model does simulate transport of emissions from the fine domain to the area, and it also simulates dust emissions using winds from the medium domain at a coarser resolution $(9 \mathrm{~km})$. However, this resolution is too coarse to represent the localized feature and to create areas of intense emissions due to local flows. The model therefore does not capture this dust event even though it simulates the presence of dust in the region.

Further examples of dust plumes are presented in the Supplement along with trajectory curtain plots. The optical properties are similar across the different events. Furthermore, there is consistency with the simulations despite the large variation in emission rates and locations. One noticeable feature of these examples is the very local character of the events which span 5 to $20 \mathrm{~km}$ horizontally.

\subsection{Urban transects}

The HSRL performed transects of the MCMA basin during most of the flights. Figure $7 \mathrm{a}$ and $\mathrm{b}$ show maps of the flight segments over the MCMA, with the corresponding HSRL 


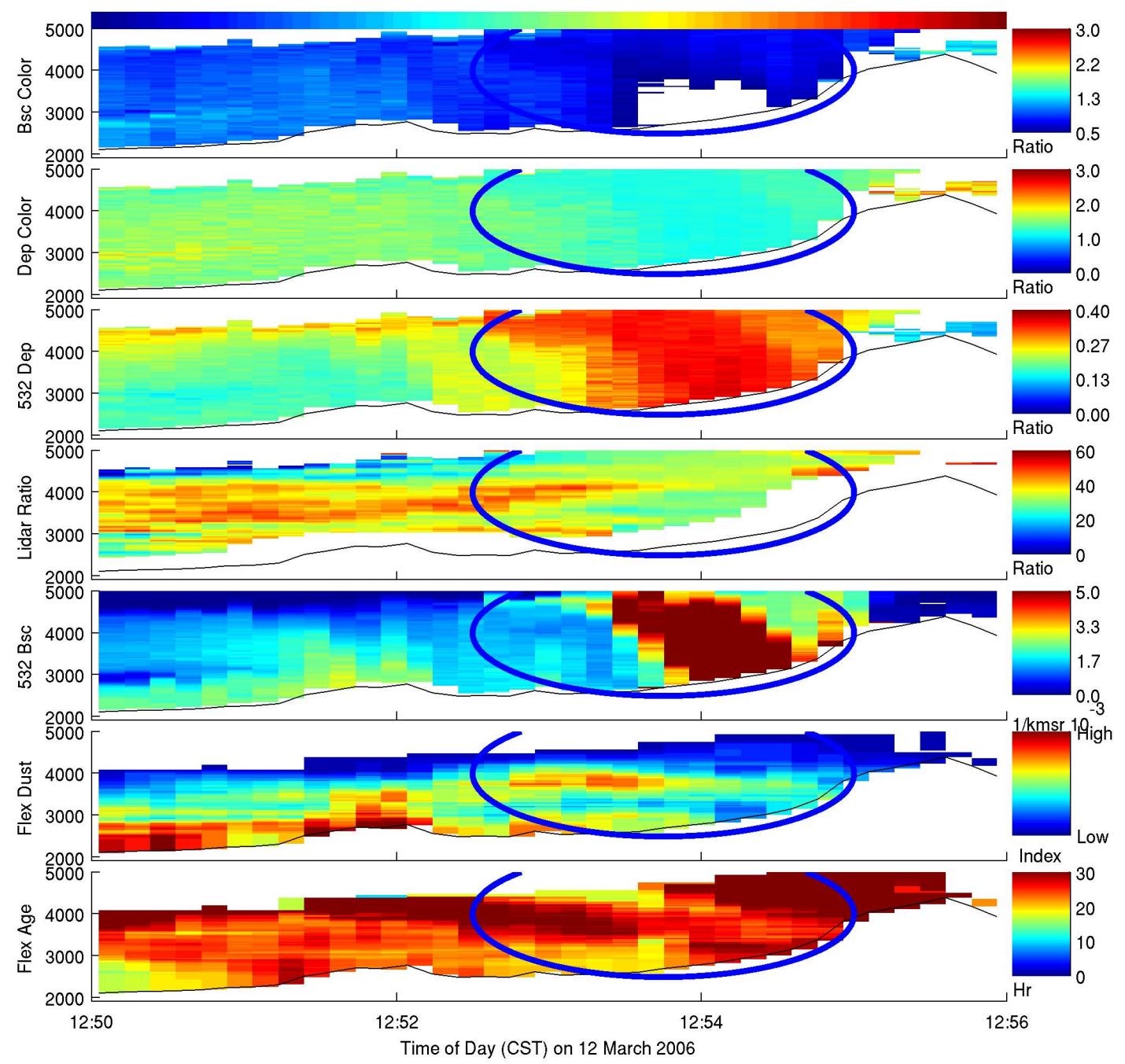

Fig. 6. Curtain plots of HSRL backscatter coefficients and intensive properties on 12 March 12:50 to 12:56 along with Flexpart mean age and particle count index for dust tracers. The blue ellipse shows a dust storm on the mountain slopes. The y-axis is height above mean sea level. The colorbar across the top corresponds to the trajectory shown in Fig. 3c.

curtains shown in Fig. 8 for the three transects on 13 March and Fig. 9 for the four transects on 15 March. In general, the transects reflect the fact that the urban area of the MCMA fills the center and the western side of the basin whereas the eastern side is more rural (see Fig. 1a).

On 13 March (Fig. 8), the northenmost transect of the HSRL was over the southern part of the basin above the MCMA. The urban emissions were sampled on the western side, as shown clearly by the simulations (see red ellipse). These aerosols have low aerosol depolarization ratios at $532 \mathrm{~nm}$, with values around 0.1 compared with regional average values from 0.1 to 0.2 , but not as low as the values of 0.05 seen for fresh biomass burning smoke. The depolarization color ratios are on the low end with values from 1.4 to 1.8 compared with a regional average from 1.5 to 2 . The backscatter color ratio has values around 1.5 that are similar to the regional average. The clearest signal of the urban plume are the high lidar ratios, with values from 50 to 60 , compared with 30 to 60 elsewhere.

On the eastern side of the basin there are high aerosol loadings in the boundary layer extending nearly $2000 \mathrm{~m}$ above ground (see turquoise rectangle). In contrast with the biomass burning plumes discussed in Sect. 4.1, this plume has high depolarization ratios at $532 \mathrm{~nm}(0.15$ to 0.2$)$, low backscatter color ratios (1 to 1.5) and low depolarization color ratios (1.4 to 1.7). The lidar ratio is not distinctive with values around 40 to 50 . The smoke is relatively fresh, but has been transported 15 to $40 \mathrm{~km}$ from the fires to the north. The simulations suggest that these are the result of biomass burning on the sides of the volcanoes combined with dust emissions, with the resulting properties being closer to those of dust than of biomass burning plumes. 

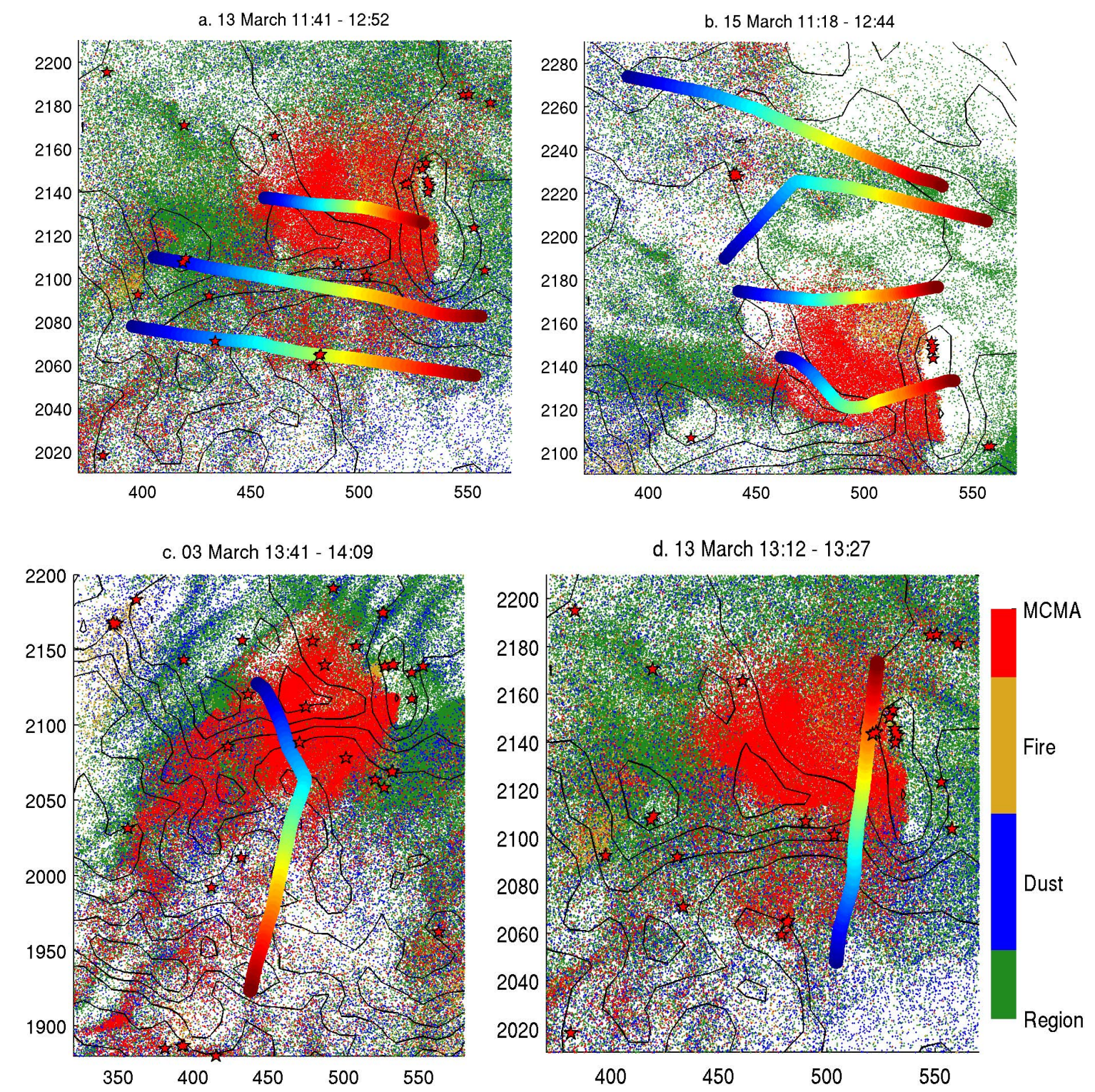

Fig. 7. Flexpart particle clouds colored by emission source using the colorbar in - bf(d). The path of the HSRL curtain plots is shown by the colored line. The corresponding profile can be found by matching the color along the flight path with the colorbar across the top of the curtain plots. (a) corresponds to Fig. 8, (b) to Fig. 9, (c) to 10 and (d) to Fig. 11. Stars indicate burning fires. Axes show Universal Transverse Mercator zone 14 coordinates in kilometers. Terrain contours shown every $500 \mathrm{~m}$.

An elevated plume rises westward from this area to nearly $5000 \mathrm{~m}$ m.s.l., shown by the yellow ellipse. This plume has low depolarization ratios and high backscatter color ratios corresponding to a fresh biomass burning plume similar to the 7 March plumes discussed in Sect. 4.1. This suggests that the elevated plume is both less aged and less mixed than the plume below.

The second transect on 13 March is over the southern side of the basin rim, over forests and smaller cities to the south. The HSRL flew over a fresh fire that can be clearly seen in the yellow ellipse above the mountain pass (the second el- lipse counting from the left margin). This fire has very high depolarization color ratios and backscatter color ratios. As the measurements move east, the aerosol layers are very inhomogeneous with patchy plumes caused by complex transport over the basin rim. Towards the middle of the transect, the yellow ellipse (third from left margin) shows an elevated plume of biomass burning that is being transported from the basin rim. It is separate from the urban transport despite being so close to it. To the east of that, in the green rectangle, the measurements cross the plume transported by the gap flow in the southeast of the basin which mixes together older 


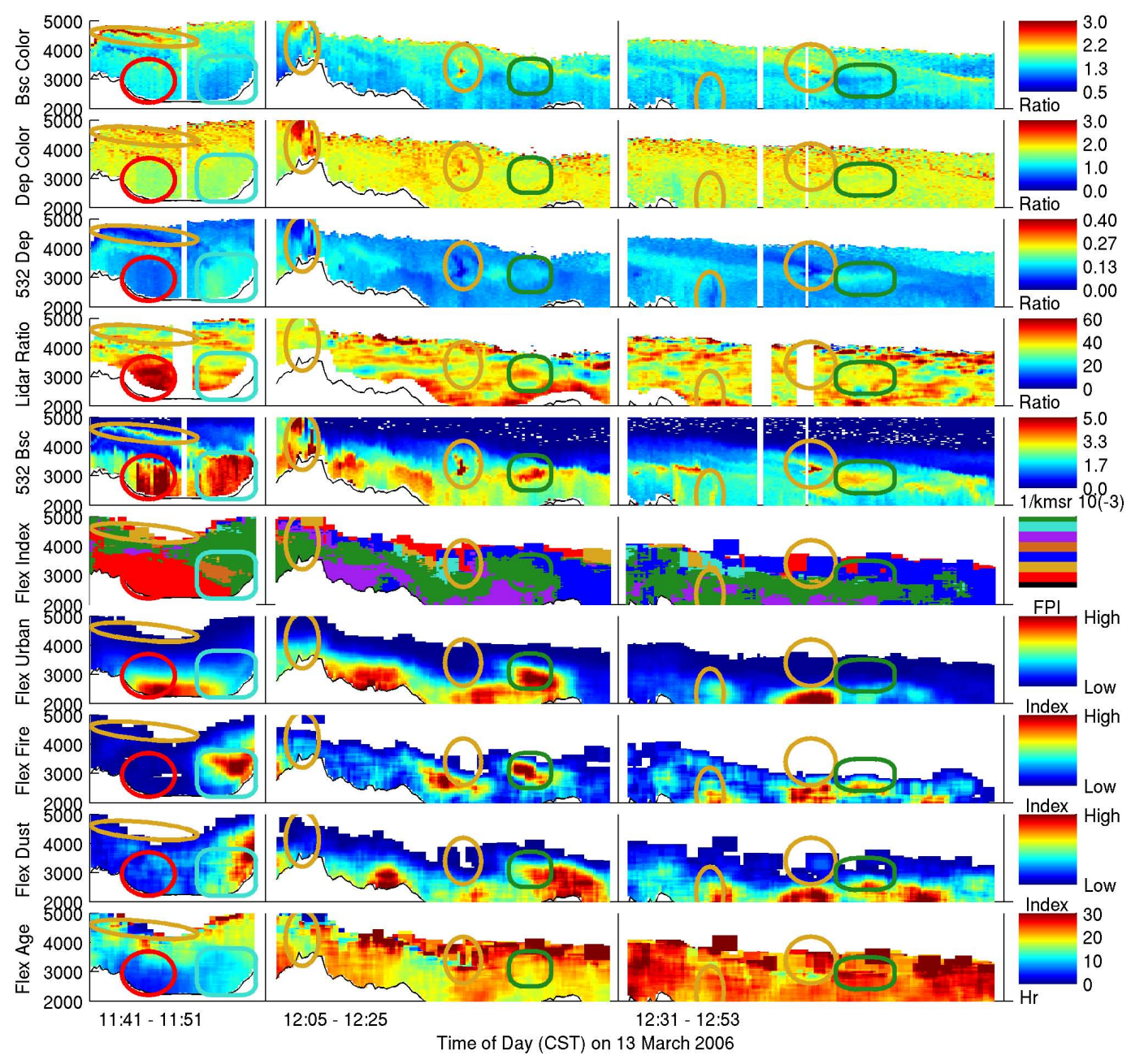

Fig. 8. Curtain plots of HSRL backscatter coefficients and intensive properties for three transects on 13 March along with Flexpart average age and particle count index for dust, fire and urban emissions. See Fig. 12 for Flexpart Particle Index (FPI) legend. The yellow ellipses show biomass burning plumes, the red ellipse shows the urban plume, the turquoise rectangle shows a biomass burning and dust mix and the green ellipses show mixed plumes. The y-axis is height above mean sea level. All transects are shown from west to east. From left to right the transects correspond to the trajectories from north to south in Fig. 7a.

biomass burning, dust and urban emissions. Because of its mixed origin, the optical properties of this elevated plume do not have a distinctive signature.

The southernmost transect shows the dust emissions from the basin rim and the elevated layers of urban mix as they are transported aloft above the valley to the south of the basin. Some of the features remain remarkably well defined as they are transported, in particular the plume of fresh smoke aloft, shown in the yellow ellipse in the middle of the transect (rightmost one). The green rectangle shows the mix that came from the gap flow. At this location, the high depolarization ratios and low backscatter color ratios can be seen more clearly. The yellow ellipse at the beginning of the transect (fourth from the left) shows a small fire with a signature of the plume rise extending to the top of the mixing layer.
One noticeable discrepancy between the simulations and the data is the large simulated fire in the middle of the transect (below the rightmost yellow ellipse) that is not seen in the measurements. Comparison with MODIS rapidfire visible imagery suggests that this was in fact a small fire with little smoke despite being detected as a MODIS hotspot.

On 15 March (Fig. 9), the HSRL measured four transects starting over the southern rim of the basin and moving north. The dominant wind transport at that time is from north to south, so the transects will be displayed in reverse order to show the transport of regional pollution moving from north to south and mixing with local emissions.

The northenmost transect detects a residual layer aloft that contains a mix of urban, biomass burning and dust (green ellipse). This is an aging layer more than one day old. The red circle to the east highlights the plume of local emissions from 


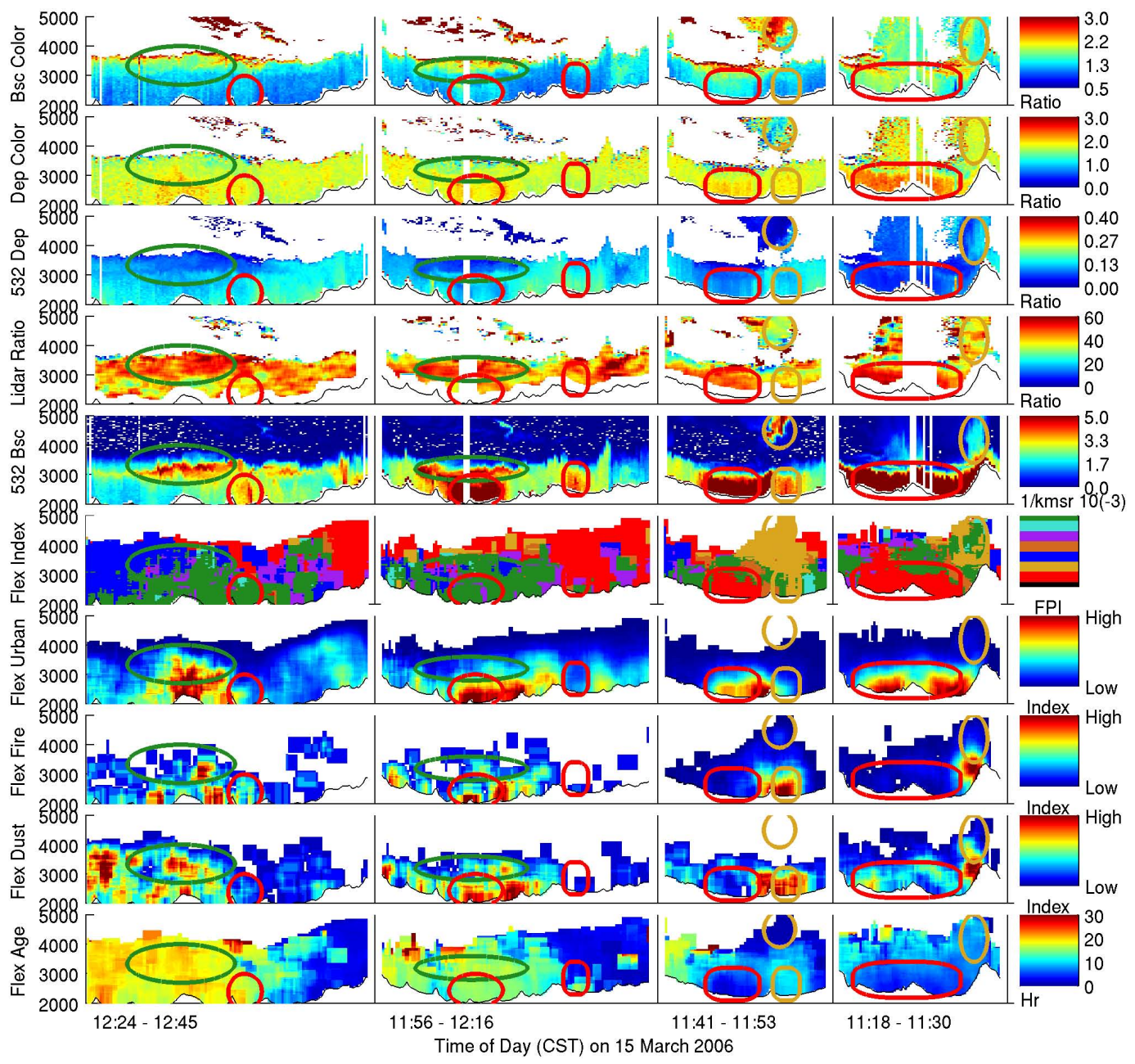

Fig. 9. Curtain plots of HSRL backscatter coefficients and intensive properties for four transects on 15 March along with Flexpart average age and particle count index for dust, fire and urban emissions. See Fig. 12 for Flexpart Particle Index (FPI) legend. The yellow ellipses show biomass burning plumes, the red ellipses show the urban plume and the green ellipses show mixed plumes. The y-axis is height above mean sea level. All transects are shown from west to east. From left to right the transects correspond to the trajectories from north to south in Fig. 7b. (Please note that the aircraft flew from south to north on this occasion, so that the first transect in time is shown on the right.)

Pachuca, a small city north of the MCMA. It extends $1000 \mathrm{~m}$ above ground but remains separated from the residual layer aloft.

Similar plumes can be seen in the second transect from the north where the residual layer (second green ellipse from the left margin) is now directly above local emissions at the surface from the Tula industrial region (second red ellipse from the left margin). The Pachuca plume can be seen in the red circle to the east (third from the left margin). The urban aerosols in the red circles have properties that are more similar to the ambient mix than to the urban plumes described above for 13 March.

The residual layer between 3000 and $4000 \mathrm{~m}$ m.s.l. has lower aerosol depolarization ratios at $532 \mathrm{~nm}(0.05$ to 0.1 , compared with 0.1 to 0.15 at the surface) and higher backscatter color ratios (1.5 to 2.5 compared with 1 to 1.5 at the surface). This suggests that the residual layer consists of smaller more spherical aerosols, most likely from a biomass burning plume with reduced dust content. The layer also has lower depolarization color ratios (1.2 to 1.8 compared with 1.6 to 2.2 at the surface). Between 4000 and $5000 \mathrm{~m}$ m.s.l., an elevated plume of biomass burning smoke is beginning to be detected which will be seen more clearly in the third and fourth transects.

During the third transect from the north, we now clearly see the urban emissions of the MCMA on the western side of the basin shown in the red ellipse (second from the right margin). The urban aerosols have the characteristic properties of the urban air mass described above for 13 March, with higher lidar ratios than the other aerosol types, low aerosol depolarization ratios at $532 \mathrm{~nm}$, high depolarization color ratio and high backscatter color ratio. There are two biomass 


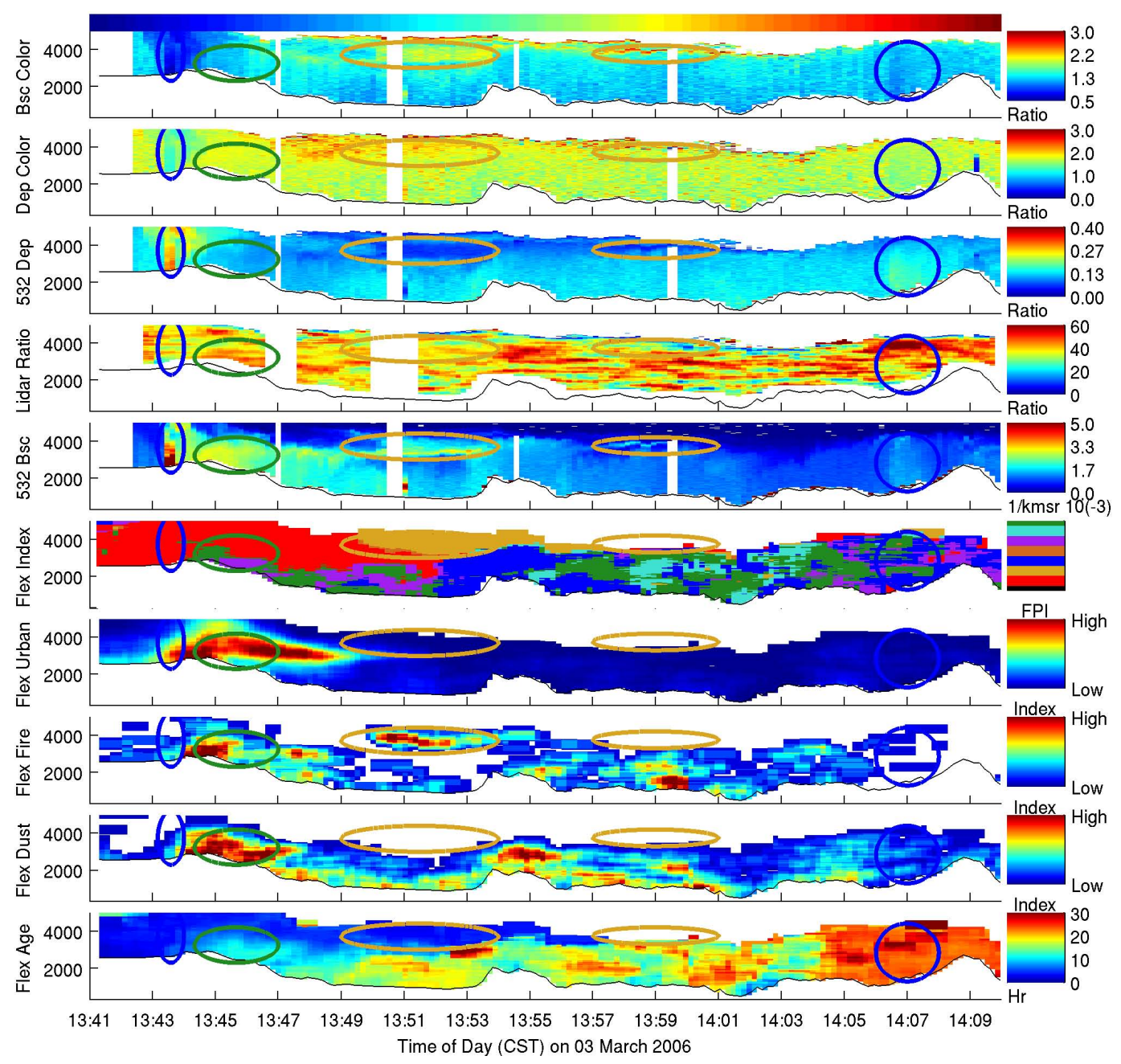

Fig. 10. Curtain plots of HSRL backscatter coefficients and intensive properties for southward flight along the urban plume on 3 March 13:41 to 14:10, along with Flexpart average age and particle count index for dust, fire and urban emissions. See Fig. 12 for Flexpart Particle Index (FPI) legend. The yellow ellipses show biomass burning plumes, the blue ellipses show dust plumes and the green ellipse shows a mixed plume. The y-axis is height above mean sea level. The colorbar across the top corresponds to the trajectory shown in Fig. 7c.

burning plumes: a surface plume that is mixed with dust (yellow ellipse from 2000 to $3000 \mathrm{~m}$ m.s.l.), and a purer elevated plume (yellow ellipse from 4000 to $5000 \mathrm{~m}$ m.s.l.). The optical properties provide a clear contrast of the two plumes, with the dust smoke mix having higher depolarization color ratios and lower backscatter color ratios whereas the purer smoke aloft has low depolarization color ratios and high backscatter color ratios.

The southernmost transect passes south of the area influenced by biomass burning and measures urban emissions across the width of the basin (rightmost red rectangle). These are emissions from the north about to be transported over the southern basin rim and through the mountain gap in the southeast. The rightmost yellow ellipse shows the biomass burning plume on the sides of the mountains. This is lofted to $5000 \mathrm{~m} \mathrm{m.s.l}$. and is the source of the high altitude plume seen in the third transect (yellow ellipse from 4000 to
$5000 \mathrm{~m}$ m.s.l.), and also seen to a lesser degree in the first two transects.

\subsection{Urban plume transport}

Figure $7 \mathrm{c}$ and $\mathrm{d}$ show the maps of the HSRL transects along the plume on 3 and 13 March with the corresponding curtain plots in Figs. 10 and 11. The flight towards the south on 3 March follows the plume as it is being transported over the basin rim and above the valley which is at much lower elevation (Figs. 7c and 10). Just before the top of the basin rim there is a plume extending $2000 \mathrm{~m}$ upwards that has the properties of dust (blue circle). The green ellipse shows the initial plume containing a mix of urban emissions, biomass burning smoke and dust. As for the transects described in Sect. 4.3, the optical properties are similar to those of the mixed regional aerosols. The plume is transported in 


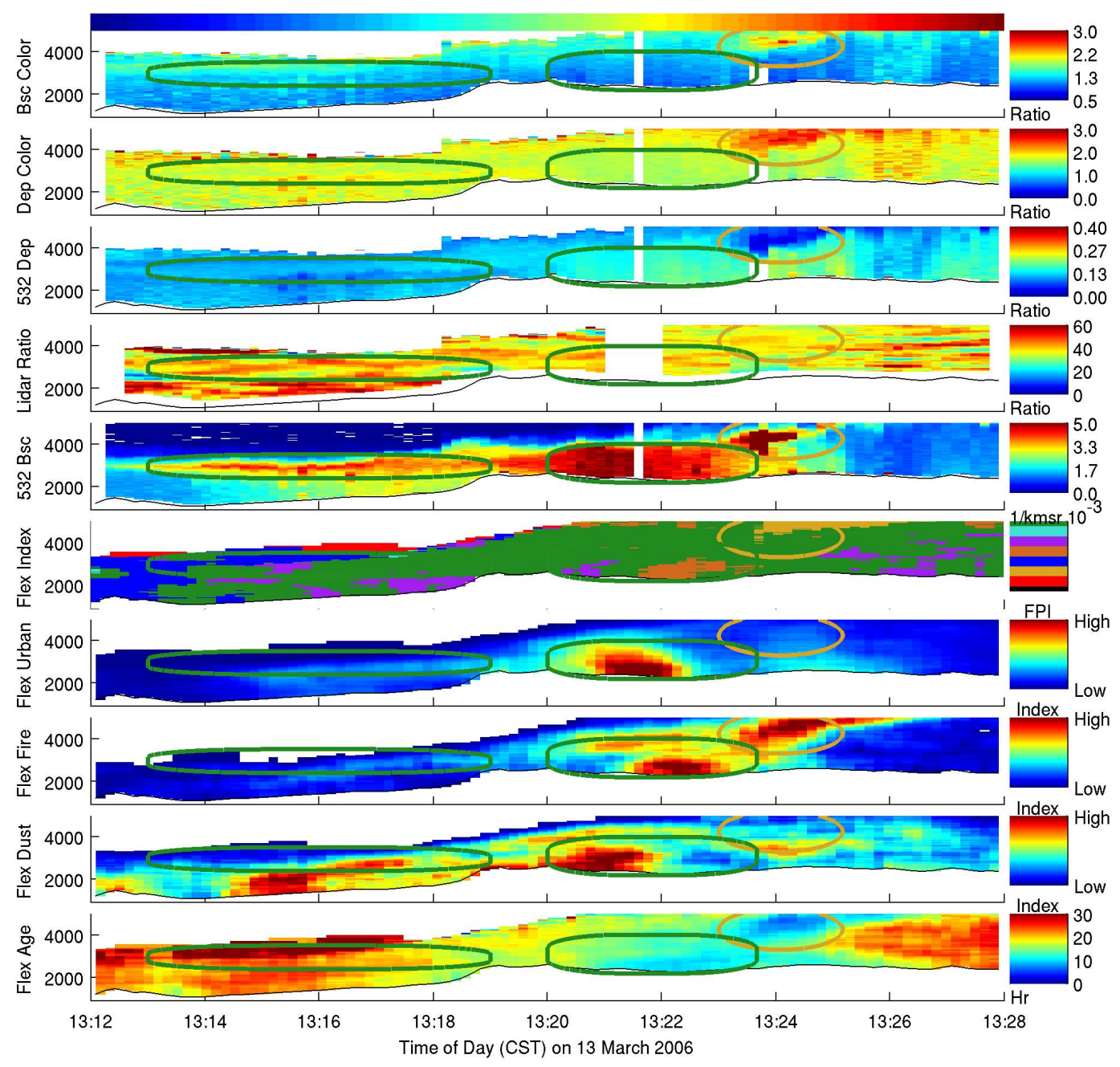

Fig. 11. Curtain plots of HSRL backscatter coefficients and intensive properties for northeastward flight through the mountain gap on 13 March 13:12 to 13:28, along with Flexpart average age and particle count index for dust, fire and urban emissions. See Fig. 12 for Flexpart Particle Index (FPI) legend. The yellow ellipse shows a biomass burning plume, and the green ellipses show mixed plume. The y-axis is height above mean sea level. The colorbar across the top corresponds to the trajectory shown in Fig. $7 \mathrm{~d}$.

layers that remain at constant elevation, with plumes from local emissions clearly separated below.

The model simulates some fresh biomass burning plume in the vicinity of $4000 \mathrm{~m}$ m.s.l., shown by the two yellow ellipses. These plumes have very fine features in the vertical showing strong vertical stratification of the flow. Furthermore, they have the depolarization and backscatter color ratios of biomass burning plumes mixed with dust. At the surface the properties are consistent with dominant wind blown dust. The blue circle on the right highlights a large dust plume. As with other dust plumes, the model simulates dust emissions in the area, but does not capture the very localized structure of the plume.

On 13 March (Figs. 7d and 11), the flight starts south of the basin, moves northeastward over the gap in the basin rim and skirts the inside edge of the basin. As can be seen in
Fig. 7d, it does not extend as far south as the flight on 3 March. South of the basin, an elevated layer at a constant height of $3000 \mathrm{~m}$ can be clearly seen with the properties of the regional mix seen in the other transects (see the green circle to the left). The transport can be clearly seen in the simulations, along with the tendency of the model to move the plume along contours of constant height above ground level rather than constant height above sea level.

Within the basin, the HSRL samples the urban plume as it moves south towards the gap (green rectangle). This contains a mix of urban emissions, biomass burning and dust, and has higher aerosol depolarization ratios at $532 \mathrm{~nm}$ than the elevated layer to the south.

The HSRL measures a very clear biomass burning plume above $3000 \mathrm{~m}$ m.s.l. (yellow ellipse). This is correctly represented in the simulations, which shows that the plume is 

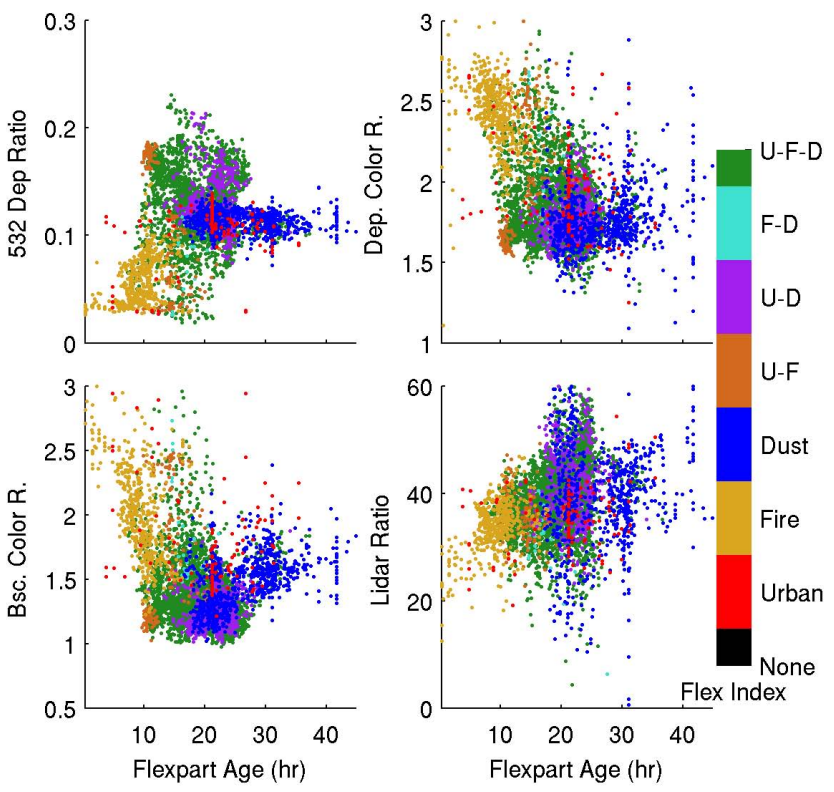

Fig. 12. Scattergram of HSRL intensive aerosol properties versus particle age simulated with Flexpart for the plume section on 13 March shown in Fig. 11. Points colored using Flexpart Particle Index (FPI).

at most a couple of hours old. This is an example of a plume with a high depolarization color ratio and mediumhigh backscatter color ratio similar to the 7 March cases (see Fig. 4).

\section{Discussion}

\subsection{Aerosol optical properties}

Table 1 presents a summary of aerosol properties measured during the MILAGRO field campaign for the main aerosol types based on the combination of data analysis and simulation comparisons. The information about aerosol morphology corresponding to high and low values of optical properties is also shown in the table.

Urban aerosols during MILAGRO had lower aerosol depolarization ratios and higher lidar ratios corresponding to more spherical and more absorbing aerosols. In contrast, dust had high aerosol depolarization ratios, low backscatter color ratios and low lidar ratios corresponding to highly nonspherical particles that are larger and absorb less. The more striking features of the analysis are the very low aerosol depolarization ratios of fresh biomass burning smoke. These are combined with higher backscatter color ratios and lidar ratios suggesting small, spherical, absorbing particles. The smoke plumes during the campaign can be separated into two types according to optical properties. The first group, "Fresh BB", is thought to consist of pure fresh smoke. The reasons for the different properties of the second group, "Fresh BB
Mix", are not certain but could be due to different types of fires or to different mixing in the plume. Many of the fires around the basin were observed to be small agricultural fires in areas with bare earth and even ploughing leading to dust emissions. As the biomass burning plumes aged, they were mixed with other plumes and ended up with the properties of dust.

Figure 12 shows a scatter plot of aerosol optical properties versus average particle age calculated from the simulations for the section through the gap flow on 13 March (see Figs. 11 and 7d). The HSRL measured a clear plume of mixed aerosols transported aloft out of the basin, and a separate plume of fresh biomass burning smoke. The scattergram clearly shows the low depolarization ratios at $532 \mathrm{~nm}$ and high depolarization color ratios and backscatter color ratios of the biomass burning smoke mixed with some dust. The plume was sampled very near the source, but within $10 \mathrm{~h}$ the optical properties have evolved to those of the mixed layer.

The ubiquitous presence of dust led to rapid convergence of aerosol optical properties as different plumes were transported away from the source regions. In addition, complex transport patterns meant that the match between observations and simulations was good qualitatively, but that significant discrepancies remained in the identification and location of plume features. For these two reasons, the present analysis of the data was only able to establish clear relationships in the evolution of aerosol optical properties for the fresh biomass burning plumes, but not for longer particle ages or for different aerosol types.

The optical properties of the aerosols sampled in and around the MCMA during MILAGRO are consistent with Querol et al. (2008) and Crounse et al. (2009) who report that there are considerable amounts of dust everywhere. Atmospheric tar balls (Posfai et al., 2004) have been detected in a number of field campaigns including MILAGRO (Yokelson et al., 2009). The very low depolarization ratios in the fresh biomass burning plumes suggests that optical properties in the early plumes are dominated by very small spherical particles. This would be consistent with the presence of tar balls. As the plumes age, they are both oxidized and mixed with other aerosols, mainly dust, which would explain the rapid evolution of the properties towards larger, more irregular aerosols that are more absorbing.

\subsection{Simulations}

The results show that there is good qualitative agreement between the simulations and measurements. Nevertheless, significant discrepancies remain in the detail of the emissions and the transport. Parker (2009) suggests the use of "Adequacy-for-Purpose" when evaluating atmospheric models rather than focusing on quality of fit between simulations and measurements (see also Oreskes (1998) and Baklanov et al. (2009) who use "Fitness-for-Purpose"). In the present context, we suggest that the simulations presented satisfy 
criteria of "Aristotelian Accuracy" (de Foy et al., 2009b) for identifying aerosol plumes and ages, but that direct pixel by pixel comparison is premature.

The limitations are due to uncertainties in meteorological simulations, the impact of sub-grid scale effects and uncertainties in emissions models. The result is that whereas WRF-Flexpart can be used to identify large features quantitatively, and finer scale ones qualitatively, a direct mapping of HSRL measurements with Flexpart simulations contains too much noise to be able to detect fine changes in aerosol properties.

Curtain plots provide valuable information on the vertical distribution of aerosol loadings. Given the complex terrain surrounding the MCMA, this serves as a challenging test case of the model representation of plume transport. These results show that there are fine features in vertical stratification that were not captured by the model, and that the simulations had a tendency to follow the terrain when the real plumes travelled at constant altitude. We increased the number of vertical levels in WRF and used 3D Lagrangian tracking with Flexpart to minimise this effect. Nonetheless, vertical diffusion coefficients and boundary layer schemes remain large sources of uncertainties, which can have significant impacts on air quality simulations (de Foy et al., 2007).

In terms of plume rise, even small fires were seen to have plumes extending vertically upwards to the top of the boundary layer. Although this would merit a more detailed treatment, a first cut analysis suggests that mixing the emissions throughout the mixing layer gives an adequate vertical distribution.

Localized dust storms were clearly identified in the HSRL data by the high depolarization ratio, low lidar ratio and low depolarization color ratios. The small scale of these features suggests that they are generated by sub-grid scale wind fields that are not represented in the model. If a significant proportion of dust is emitted by these dust storms, this suggests that an emissions model would need to include a parametrization based on sub-grid scale gust winds.

\section{Conclusions}

In summary, we find that the HSRL detects numerous meteorological flow features and can often provide qualitative information about aerosol types from the measurements of their optical properties. These can be used to evaluate numerical simulations of pollution transport to identify model strengths and weaknesses. The simulations capture the main flow directions of the aerosol plumes including complex venting patterns as they move inside the basin and are then vented outside of it. Vertical stratification is also represented, although we find that the model is too likely to follow the terrain rather than transport pollution plumes at constant altitude. In the measurements, there is very strong layering of the plumes which the model cannot represent. This may be due to a combination of sub-grid scale effects and approximations in the planetary boundary layer schemes. With the current state of simulation accuracy, the model results can be used to identify plumes and plume aging qualitatively. Direct mapping of HSRL measurements to simulated results however still remains very approximate because of mismatches in plume location.

The simulations can be used to classify the aerosol by origin and to estimate the age of the plumes. In this way, the fresh biomass burning plumes stand out as having particularly low aerosol depolarization combined with high depolarization color ratios and high backscatter color ratio. Within $10 \mathrm{~h}$ or less, the properties evolve to those more typical of mixed plumes. This suggests that the plume starts off with more spherical particles that rapidly condense to more complex shapes and provides evidence for the presence of atmospheric tar balls. Dust particles start off with the opposite properties of fresh smoke: high aerosol depolarization, low backscatter color ratio and low depolarization color ratio. Given the complex combination of aerosol sources and meteorological transport, aerosols rapidly develop into mixed particulate matter with average optical properties throughout the region.

This work focuses on the use of particle trajectories to identify transport rather than on quantitative comparisons of concentrations. These quantitative studies are precluded because we have limited the study to passive tracers with neither formation nor deposition. Nonetheless, we find that the biomass burning emission inventory from the MODIS remote sensing products detects most of the plumes measured by the HSRL. We can also clearly see the rapid mixing of the urban plume within the boundary layer at the source. This transports the aerosol aloft which then get stratified as the free tropospheric flow exports the plumes regionally. The plume rise from biomass burning was also evident leading to transport aloft. Dust storms were equally found to have considerable vertical extent, although in contrast with the biomass burning plumes, these do not persist at higher elevations suggesting that there is rapid deposition. Overall, the combination of measurements and numerical simulations provides detailed information on aerosol properties that can be used to explore plume transport and transformation as well as numerical model behavior.

\section{Supplementary material related to this article is available online at: http://www.atmos-chem-phys.net/11/3543/2011/ acp-11-3543-2011-supplement.pdf.}

Acknowledgements. We wish to thank the large number of people involved in the MILAGRO field campaign as well as those involved in monitoring in the Mexico City basin without which this study would not exist. We are grateful to the anonymous reviewers for their comments and suggestions. 
The MILAGRO field campaign was supported by the Comisión Ambiental Metropolitana of Mexico, NSF, DOE, NASA and USDA Forest Service among others. The financial support of the US National Science Foundation (awards ATM-0511803, ATM-0810931 and ATM-0810950) and the Molina Center for Strategic Studies in Energy and the Environment is gratefully acknowledged for this work.

We acknowledge the support of the NASA LaRC, NASA HQ Science Mission Directorate, and the NASA CALIPSO Project for funding the development of the HSRL instrument. The deployment of the HSRL in these field experiments were supported in part by the US Department of Energy's Atmospheric Science Program (Office of Science, BER, Grant DE-AI02-05ER63985). We also acknowledge the aircraft flight support provided by personnel in the NASA LaRC Research Services Directorate.

Edited by: U. Pöschl

\section{References}

Adachi, K. and Buseck, P. R.: Internally mixed soot, sulfates, and organic matter in aerosol particles from Mexico City, Atmos. Chem. Phys., 8, 6469-6481, doi:10.5194/acp-8-6469-2008, 2008.

Aiken, A. C., Salcedo, D., Cubison, M. J., Huffman, J. A., DeCarlo, P. F., Ulbrich, I. M., Docherty, K. S., Sueper, D., Kimmel, J. R., Worsnop, D. R., Trimborn, A., Northway, M., Stone, E. A., Schauer, J. J., Volkamer, R. M., Fortner, E., de Foy, B., Wang, J., Laskin, A., Shutthanandan, V., Zheng, J., Zhang, R., Gaffney, J., Marley, N. A., Paredes-Miranda, G., Arnott, W. P., Molina, L. T., Sosa, G., and Jimenez, J. L.: Mexico City aerosol analysis during MILAGRO using high resolution aerosol mass spectrometry at the urban supersite (T0) - Part 1: Fine particle composition and organic source apportionment, Atmos. Chem. Phys., 9, 66336653, doi:10.5194/acp-9-6633-2009, 2009.

Aiken, A. C., de Foy, B., Wiedinmyer, C., DeCarlo, P. F., Ulbrich, I. M., Wehrli, M. N., Szidat, S., Prevot, A. S. H., Noda, J., Wacker, L., Volkamer, R., Fortner, E., Wang, J., Laskin, A., Shutthanandan, V., Zheng, J., Zhang, R., Paredes-Miranda, G., Arnott, W. P., Molina, L. T., Sosa, G., Querol, X., and Jimenez, J. L.: Mexico city aerosol analysis during MILAGRO using high resolution aerosol mass spectrometry at the urban supersite (T0) - Part 2: Analysis of the biomass burning contribution and the non-fossil carbon fraction, Atmos. Chem. Phys., 10, 5315-5341, doi:10.5194/acp-10-5315-2010, 2010.

Akagi, S. K., Yokelson, R. J., Wiedinmyer, C., Alvarado, M. J., Reid, J. S., Karl, T., Crounse, J. D., and Wennberg, P. O.: Emission factors for open and domestic biomass burning for use in atmospheric models, Atmos. Chem. Phys. Discuss., 10, 2752327602, doi:10.5194/acpd-10-27523-2010, 2010.

Al-Saadi, J., Soja, A., Pierce, R. B., Szykman, J., Wiedinmyer, C., Emmons, L., Kondragunta, S., Zhang, X., Kittaka, C., Schaack, T., and Bowman, K.: Intercomparison of near-real-time biomass burning emissions estimates constrained by satellite fire data, J. Appl. Remote Sens., 2, 021504, doi:10.1117/1.2948785, 2008.

Alexander, D. T. L., Crozier, P. A., and Anderson, J. R.: Brown carbon spheres in East Asian outflow and their optical properties, Science, 321, 833-836, doi:10.1126/science.1155296, 2008.
Andreae, M. and Merlet, P.: Emission of trace gases and aerosols from biomass burning, Global Biogeochem. Cy., 15, 955-966, 2001.

Baklanov, A., Ching, J., Grimmond, C. S. B., and Martilli, A.: Model Urbanization Strategy: Summaries, Recommendations and Requirements, in: Meteorological and Air Quality Models for Urban Areas, edited by Baklanov, A., Grimmond, C. S. B., Mahura, A., and Athanassiadou, M., chap. 15, 151-162, Springer-Verlag, Berlin, Germany, 2009.

Burton, S. P., Ferrare, R. A., Hostetler, C. A., Hair, J. W., Kittaka, C., Vaughan, M. A., Obland, M. D., Rogers, R. R., Cook, A. L., Harper, D. B., and Remer, L. A.: Using airborne high spectral resolution lidar data to evaluate combined active plus passive retrievals of aerosol extinction profiles, J. Geophys. Res.-Atmos., 115, D00H15, doi:10.1029/2009JD012130, 2010.

Cattrall, C., Reagan, J., Thome, K., and Dubovik, O.: Variability of aerosol and spectral lidar and backscatter and extinction ratios of key aerosol types derived from selected Aerosol Robotic Network locations, J. Geophys. Res.-Atmos., 110, D10S11, doi:10.1029/2004JD005124, 2005.

Chakrabarty, R., Moosmuller, H., Garro, M., Arnott, W., Walker, J., Susott, R., Babbitt, R., Wold, C., Lincoln, E., and Hao, W.: Emissions from the laboratory combustion of wildland fuels: Particle morphology and size, J. Geophys. Res.-Atmos., 111, D07204, doi:10.1029/2005JD006659, 2006.

Chakrabarty, R. K., Moosmüller, H., Chen, L.-W. A., Lewis, K., Arnott, W. P., Mazzoleni, C., Dubey, M. K., Wold, C. E., Hao, W. M., and Kreidenweis, S. M.: Brown carbon in tar balls from smoldering biomass combustion, Atmos. Chem. Phys., 10, 6363-6370, doi:10.5194/acp-10-6363-2010, 2010.

Christian, T. J., Yokelson, R. J., Crdenas, B., Molina, L. T., Engling, G., and Hsu, S.-C.: Trace gas and particle emissions from domestic and industrial biofuel use and garbage burning in central Mexico, Atmos. Chem. Phys., 10, 565-584, doi:10.5194/acp-10565-2010, 2010.

Crounse, J. D., DeCarlo, P. F., Blake, D. R., Emmons, L. K., Campos, T. L., Apel, E. C., Clarke, A. D., Weinheimer, A. J., McCabe, D. C., Yokelson, R. J., Jimenez, J. L., and Wennberg, P. O.: Biomass burning and urban air pollution over the Central Mexican Plateau, Atmos. Chem. Phys., 9, 4929-4944, doi:10.5194/acp-9-4929-2009, 2009.

de Foy, B., Caetano, E., Magaña, V., Zitácuaro, A., Cárdenas, B., Retama, A., Ramos, R., Molina, L. T., and Molina, M. J.: Mexico City basin wind circulation during the MCMA-2003 field campaign, Atmos. Chem. Phys., 5, 2267-2288, doi:10.5194/acp-52267-2005, 2005.

de Foy, B., Clappier, A., Molina, L. T., and Molina, M. J.: Distinct wind convergence patterns in the Mexico City basin due to the interaction of the gap winds with the synoptic flow, Atmos. Chem. Phys., 6, 1249-1265, doi:10.5194/acp-6-1249-2006, 2006a.

de Foy, B., Molina, L. T., and Molina, M. J.: Satellite-derived land surface parameters for mesoscale modelling of the Mexico City basin, Atmos. Chem. Phys., 6, 1315-1330, doi:10.5194/acp-61315-2006, 2006b.

de Foy, B., Varela, J. R., Molina, L. T., and Molina, M. J.: Rapid ventilation of the Mexico City basin and regional fate of the urban plume, Atmos. Chem. Phys., 6, 2321-2335, doi:10.5194/acp-6-2321-2006, 2006c.

de Foy, B., Lei, W., Zavala, M., Volkamer, R., Samuelsson, J., Mel- 
lqvist, J., Galle, B., Martínez, A.-P., Grutter, M., Retama, A., and Molina, L. T.: Modelling constraints on the emission inventory and on vertical dispersion for $\mathrm{CO}$ and $\mathrm{SO}_{2}$ in the Mexico City Metropolitan Area using Solar FTIR and zenith sky UV spectroscopy, Atmos. Chem. Phys., 7, 781-801, doi:10.5194/acp-7781-2007, 2007.

de Foy, B., Fast, J. D., Paech, S. J., Phillips, D., Walters, J. T., Coulter, R. L., Martin, T. J., Pekour, M. S., Shaw, W. J., Kastendeuch, P. P., Marley, N. A., Retama, A., and Molina, L. T.: Basinscale wind transport during the MILAGRO field campaign and comparison to climatology using cluster analysis, Atmos. Chem. Phys., 8, 1209-1224, doi:10.5194/acp-8-1209-2008, 2008.

de Foy, B., Krotkov, N. A., Bei, N., Herndon, S. C., Huey, L. G., Martínez, A.-P., Ruiz-Suárez, L. G., Wood, E. C., Zavala, M., and Molina, L. T.: Hit from both sides: tracking industrial and volcanic plumes in Mexico City with surface measurements and OMI SO2 retrievals during the MILAGRO field campaign, Atmos. Chem. Phys., 9, 9599-9617, doi:10.5194/acp-9-9599-2009, 2009a.

de Foy, B., Zavala, M., Bei, N., and Molina, L. T.: Evaluation of WRF mesoscale simulations and particle trajectory analysis for the MILAGRO field campaign, Atmos. Chem. Phys., 9, 44194438, doi:10.5194/acp-9-4419-2009, 2009b.

DeCarlo, P. F., Dunlea, E. J., Kimmel, J. R., Aiken, A. C., Sueper, D., Crounse, J., Wennberg, P. O., Emmons, L., Shinozuka, Y., Clarke, A., Zhou, J., Tomlinson, J., Collins, D. R., Knapp, D., Weinheimer, A. J., Montzka, D. D., Campos, T., and Jimenez, J. L.: Fast airborne aerosol size and chemistry measurements above Mexico City and Central Mexico during the MILAGRO campaign, Atmos. Chem. Phys., 8, 4027-4048, doi:10.5194/acp8-4027-2008, 2008.

DeCarlo, P. F., Ulbrich, I. M., Crounse, J., de Foy, B., Dunlea, E. J., Aiken, A. C., Knapp, D., Weinheimer, A. J., Campos, T., Wennberg, P. O., and Jimenez, J. L.: Investigation of the sources and processing of organic aerosol over the Central Mexican Plateau from aircraft measurements during MILAGRO, Atmos. Chem. Phys., 10, 5257-5280, doi:10.5194/acp-10-52572010, 2010.

Doran, J. C., Barnard, J. C., Arnott, W. P., Cary, R., Coulter, R., Fast, J. D., Kassianov, E. I., Kleinman, L., Laulainen, N. S., Martin, T., Paredes-Miranda, G., Pekour, M. S., Shaw, W. J., Smith, D. F., Springston, S. R., and Yu, X.-Y.: The T1-T2 study: evolution of aerosol properties downwind of Mexico City, Atmos. Chem. Phys., 7, 1585-1598, doi:10.5194/acp-7-1585-2007, 2007.

Doran, J. C., Fast, J. D., Barnard, J. C., Laskin, A., Desyaterik, Y., and Gilles, M. K.: Applications of lagrangian dispersion modeling to the analysis of changes in the specific absorption of elemental carbon, Atmos. Chem. Phys., 8, 1377-1389, doi:10.5194/acp-8-1377-2008, 2008.

Fast, J., Aiken, A. C., Allan, J., Alexander, L., Campos, T., Canagaratna, M. R., Chapman, E., DeCarlo, P. F., de Foy, B., Gaffney, J., de Gouw, J., Doran, J. C., Emmons, L., Hodzic, A., Herndon, S. C., Huey, G., Jayne, J. T., Jimenez, J. L., Kleinman, L., Kuster, W., Marley, N., Russell, L., Ochoa, C., Onasch, T. B., Pekour, M., Song, C., Ulbrich, I. M., Warneke, C., WelshBon, D., Wiedinmyer, C., Worsnop, D. R., Yu, X.-Y., and Zaveri, R.: Evaluating simulated primary anthropogenic and biomass burning organic aerosols during MILAGRO: implications for as- sessing treatments of secondary organic aerosols, Atmos. Chem. Phys., 9, 6191-6215, doi:10.5194/acp-9-6191-2009, 2009.

Fast, J. D. and Easter, R.: A Lagrangian Particle Dispersion Model Compatible with WRF, in: 7th WRF User's Workshop, Boulder, CO, USA, 2006.

Fast, J. D. and Zhong, S. Y.: Meteorological factors associated with inhomogeneous ozone concentrations within the Mexico City basin, J. Geophys. Res.-Atmos., 103, 18927-18946, 1998.

Fast, J. D., de Foy, B., Acevedo Rosas, F., Caetano, E., Carmichael, G., Emmons, L., McKenna, D., Mena, M., Skamarock, W., Tie, X., Coulter, R. L., Barnard, J. C., Wiedinmyer, C., and Madronich, S.: A meteorological overview of the MILAGRO field campaigns, Atmos. Chem. Phys., 7, 2233-2257, doi:10.5194/acp-7-2233-2007, 2007.

Ferrare, R. A., Burton, S. P., Hostetler, C. A., Hair, J. W., Rogers, R. R., Obland, M. D., Cook, A. L., and Harper, D. B.: Aerosol Classification of Airborne High Spectral Resolution Lidar Measurements, in preparation, 2011.

Friedl, M. A., Sulla-Menashe, D., Tan, B., Schneider, A., Ramankutty, N., Sibley, A., and Huang, X.: MODIS Collection 5 global land cover: Algorithm refinements and characterization of new datasets, Remote Sens. Environ., 114, 168-182, doi:10.1016/j.rse.2009.08.016, 2010.

Giglio, L., Descloitres, J., Justice, C., and Kaufman, Y.: An enhanced contextual fire detection algorithm for MODIS, Remote Sens. Environ., 87, 273-282, doi:10.1016/S00344257(03)00184-6, 2003.

Hair, J. W., Hostetler, C. A., Cook, A. L., Harper, D. B., Ferrare, R. A., Mack, T. L., Welch, W., Izquierdo, L. R., and Hovis, F. E.: Airborne High Spectral Resolution Lidar for profiling aerosol optical properties, Appl. Optics, 47, 6734-6752, 2008.

Hand, J., Malm, W., Laskin, A., Day, D., Lee, T., Wang, C., Carrico, C., Carrillo, J., Cowin, J., Collett, J., and Iedema, M.: Optical, physical, and chemical properties of tar balls observed during the Yosemite Aerosol Characterization Study, J. Geophys. Res.Atmos., 110, D21210, doi:10.1029/2004JD005728, 2005.

Hodzic, A., Jimenez, J. L., Madronich, S., Aiken, A. C., Bessagnet, B., Curci, G., Fast, J., Lamarque, J.-F., Onasch, T. B., Roux, G., Schauer, J. J., Stone, E. A., and Ulbrich, I. M.: Modeling organic aerosols during MILAGRO: importance of biogenic secondary organic aerosols, Atmos. Chem. Phys., 9, 6949-6981, doi:10.5194/acp-9-6949-2009, 2009.

Hoelzemann, J., Schultz, M., Brasseur, G., Granier, C., and Simon, M.: Global Wildland Fire Emission Model (GWEM): Evaluating the use of global area burnt satellite data, J. Geophys. Res.Atmos., 109, D21210, doi:10.1029/2003JD003666, 2004.

Hong, S. Y., Noh, Y., and Dudhia, J.: A new vertical diffusion package with an explicit treatment of entrainment processes, Mon. Weather Rev., 134, 2318-2341, 2006.

Janhäll, S., Andreae, M. O., and Pöschl, U.: Biomass burning aerosol emissions from vegetation fires: particle number and mass emission factors and size distributions, Atmos. Chem. Phys., 10, 1427-1439, doi:10.5194/acp-10-1427-2010, 2010.

Jazcilevich, A. D., Garcia, A. R., and Caetano, E.: Locally induced surface air confluence by complex terrain and its effects on air pollution in the valley of Mexico, Atmos. Environ., 39, 54815489, 2005.

Jimenez, J. L., Canagaratna, M. R., Donahue, N. M., Prevot, A. S. H., Zhang, Q., Kroll, J. H., DeCarlo, P. F., Allan, J. D., Coe, 
H., Ng, N. L., Aiken, A. C., Docherty, K. S., Ulbrich, I. M., Grieshop, A. P., Robinson, A. L., Duplissy, J., Smith, J. D., Wilson, K. R., Lanz, V. A., Hueglin, C., Sun, Y. L., Tian, J., Laaksonen, A., Raatikainen, T., Rautiainen, J., Vaattovaara, P., Ehn, M., Kulmala, M., Tomlinson, J. M., Collins, D. R., Cubison, M. J., Dunlea, E. J., Huffman, J. A., Onasch, T. B., Alfarra, M. R., Williams, P. I., Bower, K., Kondo, Y., Schneider, J., Drewnick, F., Borrmann, S., Weimer, S., Demerjian, K., Salcedo, D., Cottrell, L., Griffin, R., Takami, A., Miyoshi, T., Hatakeyama, S., Shimono, A., Sun, J. Y., Zhang, Y. M., Dzepina, K., Kimmel, J. R., Sueper, D., Jayne, J. T., Herndon, S. C., Trimborn, A. M., Williams, L. R., Wood, E. C., Middlebrook, A. M., Kolb, C. E., Baltensperger, U., and Worsnop, D. R.: Evolution of Organic Aerosols in the Atmosphere, Science, 326, 1525-1529, doi:10.1126/science.1180353, 2009.

Kain, J. S.: The Kain-Fritsch convective parameterization: An update, J. Appl. Meteorol., 43, 170-181, 2004.

Karydis, V. A., Tsimpidi, A. P., Fountoukis, C., Nenes, A., Zavala, M., Lei, W., Molina, L. T., and Pandis, S. N.: Simulating the fine and coarse inorganic particulate matter concentrations in a polluted megacity, Atmos. Environ., 44, 608-620, doi:10.1016/j.atmosenv.2009.11.023, 2010.

Kleinman, L. I., Springston, S. R., Daum, P. H., Lee, Y.-N., Nunnermacker, L. J., Senum, G. I., Wang, J., Weinstein-Lloyd, J., Alexander, M. L., Hubbe, J., Ortega, J., Canagaratna, M. R., and Jayne, J.: The time evolution of aerosol composition over the Mexico City plateau, Atmos. Chem. Phys., 8, 1559-1575, doi:10.5194/acp-8-1559-2008, 2008.

Kleinman, L. I., Springston, S. R., Wang, J., Daum, P. H., Lee, Y.-N., Nunnermacker, L. J., Senum, G. I., Weinstein-Lloyd, J., Alexander, M. L., Hubbe, J., Ortega, J., Zaveri, R. A., Canagaratna, M. R., and Jayne, J.: The time evolution of aerosol size distribution over the Mexico City plateau, Atmos. Chem. Phys., 9, 4261-4278, doi:10.5194/acp-9-4261-2009, 2009.

Lei, W., de Foy, B., Zavala, M., Volkamer, R., and Molina, L. T.: Characterizing ozone production in the Mexico City Metropolitan Area: a case study using a chemical transport model, Atmos. Chem. Phys., 7, 1347-1366, doi:10.5194/acp-7-1347-2007, 2007.

Lewandowski, P. A., Eichinger, W. E., Holder, H., Prueger, J., Wang, J., and Kleinman, L. I.: Vertical distribution of aerosols in the vicinity of Mexico City during MILAGRO-2006 Campaign, Atmos. Chem. Phys., 10, 1017-1030, doi:10.5194/acp-10-10172010, 2010.

Mena-Carrasco, M., Carmichael, G. R., Campbell, J. E., Zimmerman, D., Tang, Y., Adhikary, B., D'allura, A., Molina, L. T., Zavala, M., Garca, A., Flocke, F., Campos, T., Weinheimer, A. J., Shetter, R., Apel, E., Montzka, D. D., Knapp, D. J., and Zheng, W.: Assessing the regional impacts of Mexico City emissions on air quality and chemistry, Atmos. Chem. Phys., 9, 3731-3743, doi:10.5194/acp-9-3731-2009, 2009.

MODIS Rapid Response project: MODIS Hotspot/Active Fire Detections Data set, Tech. rep., NASA/University of Maryland, available online at: http://maps.geog.umd.edu, 2002.

Moffet, R. C., Henn, T. R., Tivanski, A. V., Hopkins, R. J., Desyaterik, Y., Kilcoyne, A. L. D., Tyliszczak, T., Fast, J., Barnard, J., Shutthanandan, V., Cliff, S. S., Perry, K. D., Laskin, A., and Gilles, M. K.: Microscopic characterization of carbonaceous aerosol particle aging in the outflow from Mexico City, Atmos.
Chem. Phys., 10, 961-976, doi:10.5194/acp-10-961-2010, 2010.

Molina, L. T. and Molina, M. J. (Eds.): Air Quality in the Mexico Megacity: An Integrated Assessment, Kluwer Academic Publishers, Dordrecht, The Netherlands, Chapter 3, 105-122, 2002.

Molina, L. T., Kolb, C. E., de Foy, B., Lamb, B. K., Brune, W. H., Jimenez, J. L., Ramos-Villegas, R., Sarmiento, J., ParamoFigueroa, V. H., Cardenas, B., Gutierrez-Avedoy, V., and Molina, M. J.: Air quality in North America's most populous city overview of the MCMA-2003 campaign, Atmos. Chem. Phys., 7, 2447-2473, doi:10.5194/acp-7-2447-2007, 2007.

Molina, L. T., Madronich, S., Gaffney, J. S., Apel, E., de Foy, B., Fast, J., Ferrare, R., Herndon, S., Jimenez, J. L., Lamb, B., Osornio-Vargas, A. R., Russell, P., Schauer, J. J., Stevens, P. S., Volkamer, R., and Zavala, M.: An overview of the MILAGRO 2006 Campaign: Mexico City emissions and their transport and transformation, Atmos. Chem. Phys., 10, 8697-8760, doi:10.5194/acp-10-8697-2010, 2010.

Müller, D., Ansmann, A., Mattis, I., Tesche, M., Wandinger, U., Althausen, D., and Pisani, G.: Aerosol-type-dependent lidar ratios observed with Raman lidar, J. Geophys. Res.-Atmos., 112, D16202, doi:10.1029/2006JD008292, 2007.

Oreskes, N.: Evaluation (not validation) of quantitative models, Environ. Health Perspect., 106, 1453-1460, 1998.

Parker, W. S.: II - Confirmation and Adequacy-for-Purpose in Climate Modelling, Proceedings of the Aristotelian Society Supplementary Volume, 83, 233-249, doi:10.1111/j.14678349.2009.00180.x, 2009.

Posfai, M. and Buseck, P. R.: Nature and Climate Effects of Individual Tropospheric Aerosol Particles, Annu. Rev. Earth Planet. Sci., 38, 17-43, doi:10.1146/annurev.earth.031208.100032, 2010.

Posfai, M., Gelencser, A., Simonics, R., Arato, K., Li, J., Hobbs, P., and Buseck, P.: Atmospheric tar balls: Particles from biomass and biofuel burning, J. Geophys. Res.-Atmos., 109, D06213, doi:10.1029/2003JD004169, 2004.

Qian, Y., Gustafson Jr., W. I., and Fast, J. D.: An investigation of the sub-grid variability of trace gases and aerosols for global climate modeling, Atmos. Chem. Phys., 10, 6917-6946, doi:10.5194/acp-10-6917-2010, 2010.

Querol, X., Pey, J., Minguillón, M. C., Pérez, N., Alastuey, A., Viana, M., Moreno, T., Bernabé, R. M., Blanco, S., Cárdenas, B., Vega, E., Sosa, G., Escalona, S., Ruiz, H., and Artíñano, B.: PM speciation and sources in Mexico during the MILAGRO-2006 Campaign, Atmos. Chem. Phys., 8, 111-128, doi:10.5194/acp8-111-2008, 2008.

Raga, G. B., Baumgardner, D., Castro, T., Martinez-Arroyo, A., and Navarro-Gonzalez, R.: Mexico City air quality: A qualitative review of gas and aerosol measurements (1960-2000), Atmos. Environ., 35, 4041-4058, 2001.

Reid, J. S., Eck, T. F., Christopher, S. A., Koppmann, R., Dubovik, O., Eleuterio, D. P., Holben, B. N., Reid, E. A., and Zhang, J.: A review of biomass burning emissions part III: intensive optical properties of biomass burning particles, Atmos. Chem. Phys., 5, 827-849, doi:10.5194/acp-5-827-2005, 2005.

Rogers, R. R., Hair, J. W., Hostetler, C. A., Ferrare, R. A., Obland, M. D., Cook, A. L., Harper, D. B., Burton, S. P., Shinozuka, Y., McNaughton, C. S., Clarke, A. D., Redemann, J., Russell, P. B., Livingston, J. M., and Kleinman, L. I.: NASA LaRC airborne high spectral resolution lidar aerosol measurements during MI- 
LAGRO: observations and validation, Atmos. Chem. Phys., 9, 4811-4826, doi:10.5194/acp-9-4811-2009, 2009.

Salcedo, D., Onasch, T. B., Dzepina, K., Canagaratna, M. R., Zhang, Q., Huffman, J. A., DeCarlo, P. F., Jayne, J. T., Mortimer, P., Worsnop, D. R., Kolb, C. E., Johnson, K. S., Zuberi, B., Marr, L. C., Volkamer, R., Molina, L. T., Molina, M. J., Cardenas, B., Bernabé, R. M., Márquez, C., Gaffney, J. S., Marley, N. A., Laskin, A., Shutthanandan, V., Xie, Y., Brune, W., Lesher, R., Shirley, T., and Jimenez, J. L.: Characterization of ambient aerosols in Mexico City during the MCMA-2003 campaign with Aerosol Mass Spectrometry: results from the CENICA Supersite, Atmos. Chem. Phys., 6, 925-946, doi:10.5194/acp-6-9252006, 2006.

Sasano, Y. and Browell, E. V.: Light-Scattering Characteristics of Various Aerosol Types Derived from Multiple Wavelength Lidar Observations, Appl. Optics, 28, 1670-1679, 1989.

Secretaría del Medio Ambiente del Gobierno del Distrito Federal: Inventario de Emisiones de Contaminantes Criterio para el Año 2006 de la Zona Metropolitana del Valle de México, Tech. Rep. (Web), Secretaría del Medio Ambiente, Gobierno del Distrito Federal, México, available online at: http://www.sma.df.gob. $\mathrm{mx} /, 2008$.

Semeniuk, T. A., Wise, M. E., Martin, S. T., Russell, L. M., and Buseck, P. R.: Hygroscopic behavior of aerosol particles from biomass fires using environmental transmission electron microscopy, J. Atmos. Chem., 56, 259-273, doi:10.1007/s10874006-9055-5, 2007.

Shaw, W. J., Pekour, M. S., Coulter, R. L., Martin, T. J., and Walters, J. T.: The daytime mixing layer observed by radiosonde, profiler, and lidar during MILAGRO, Atmos. Chem. Phys. Discuss., 7, 15025-15065, doi:10.5194/acpd-7-15025-2007, 2007.

Shaw, W. J., Allwine, K. J., Fritz, B. G., Rutz, F. C., Rishel, J. P., and Chapman, E. G.: Evaluation of the wind erosion module in DUSTRAN, Atmos. Environ., 42, 1907-1921, doi:10.1016/j.atmosenv.2007.11.022, 2008.

Shipley, S. T., Tracy, D. H., Eloranta, E. W., Trauger, J. T., Sroga, J. T., Roesler, F. L., and Weinman, J. A.: High spectral resolution lidar to measure optical scattering properties of atmospheric aerosols. 1: Theory and instrumentation, Appl. Opt., 22, 37163724, http://ao.osa.org/abstract.cfm?URI=ao-22-23-3716, 1983.

Skamarock, W. C., Klemp, J. B., Dudhia, J., Gill, D. O., Barker, D. M., Wang, W., and Powers, J. G.: A Description of the Advanced Research WRF Version 2, Tech. Rep. NCAR/TN468+STR, NCAR, 2005.

Song, J., Lei, W., Bei, N., Zavala, M., de Foy, B., Volkamer, R., Cardenas, B., Zheng, J., Zhang, R., and Molina, L. T.: Ozone response to emission changes: a modeling study during the MCMA-2006/MILAGRO Campaign, Atmos. Chem. Phys., 10, 3827-3846, doi:10.5194/acp-10-3827-2010, 2010.

Stohl, A., Forster, C., Frank, A., Seibert, P., and Wotawa, G.: Technical note: The Lagrangian particle dispersion model FLEXPART version 6.2, Atmos. Chem. Phys., 5, 2461-2474, doi:10.5194/acp-5-2461-2005, 2005.

Stone, E. A., Snyder, D. C., Sheesley, R. J., Sullivan, A. P., Weber, R. J., and Schauer, J. J.: Source apportionment of fine organic aerosol in Mexico City during the MILAGRO experiment 2006, Atmos. Chem. Phys., 8, 1249-1259, doi:10.5194/acp-81249-2008, 2008.
Sugimoto, N. and Lee, C. H.: Characteristics of dust aerosols inferred from lidar depolarization measurements at two wavelengths, Appl. Optics, 45, 7468-7474, 2006.

Voss, P. B., Zaveri, R. A., Flocke, F. M., Mao, H., Hartley, T. P., DeAmicis, P., Deonandan, I., Contreras-Jiménez, G., MartínezAntonio, O., Figueroa Estrada, M., Greenberg, D., Campos, T. L., Weinheimer, A. J., Knapp, D. J., Montzka, D. D., Crounse, J. D., Wennberg, P. O., Apel, E., Madronich, S., and de Foy, B.: Long-range pollution transport during the MILAGRO-2006 campaign: a case study of a major Mexico City outflow event using free-floating altitude-controlled balloons, Atmos. Chem. Phys., 10, 7137-7159, doi:10.5194/acp-10-7137-2010, 2010.

Warneke, C., Froyd, K. D., Brioude, J., Bahreini, R., Brock, C. A., Cozic, J., de Gouw, J. A., Fahey, D. W., Ferrare, R., Holloway, J. S., Middlebrook, A. M., Miller, L., Montzka, S., Schwarz, J. P., Sodemann, H., Spackman, J. R., and Stohl, A.: An important contribution to springtime Arctic aerosol from biomass burning in Russia, Geophys. Res. Lett., 37, L01801, doi:10.1029/2009GL041816, 2010.

Watson, J. G. and Chow, J. C.: Reconciling Urban Fugitive Dust Emissions Inventory and Ambient Source Contribution Estimates: Summary of Current Knowledge and Needed Research, Tech. Rep. DRI 6110.4F, Desert Research Institute, http://www. epa.gov/ttn/chief/efdocs/fugitivedust.pdf, 2000.

Wiedinmyer, C., Akagi, S. K., Yokelson, R. J., Emmons, L. K., AlSaadi, J. A., Orlando, J. J., and Soja, A. J.: The Fire INventory from NCAR (FINN) - a high resolution global model to estimate the emissions from open burning, Geosci. Model Dev. Discuss., 3, 2439-2476, doi:10.5194/gmdd-3-2439-2010, 2010.

Wiedinmyer, C., Quayle, B., Geron, C., Belote, A., McKenzie, D., Zhang, X., O'Neill, S., and Wynne, K. K.: Estimating emissions from fires in North America for air quality modeling, Atmospheric Environment, 40, 3419-3432, doi:10.1016/j.atmosenv.2006.02.010, 2006.

Yokelson, R. J., Urbanski, S. P., Atlas, E. L., Toohey, D. W., Alvarado, E. C., Crounse, J. D., Wennberg, P. O., Fisher, M. E., Wold, C. E., Campos, T. L., Adachi, K., Buseck, P. R., and Hao, W. M.: Emissions from forest fires near Mexico City, Atmos. Chem. Phys., 7, 5569-5584, doi:10.5194/acp-7-5569-2007, 2007.

Yokelson, R. J., Crounse, J. D., DeCarlo, P. F., Karl, T., Urbanski, S., Atlas, E., Campos, T., Shinozuka, Y., Kapustin, V., Clarke, A. D., Weinheimer, A., Knapp, D. J., Montzka, D. D., Holloway, J., Weibring, P., Flocke, F., Zheng, W., Toohey, D., Wennberg, P. O., Wiedinmyer, C., Mauldin, L., Fried, A., Richter, D., Walega, J., Jimenez, J. L., Adachi, K., Buseck, P. R., Hall, S. R., and Shetter, R.: Emissions from biomass burning in the Yucatan, Atmos. Chem. Phys., 9, 5785-5812, doi:10.5194/acp-9-5785-2009, 2009.

Yokelson, R. J., Burling, I. R., Urbanski, S. P., Atlas, E. L., Adachi, K., Buseck, P. R., Wiedinmyer, C., Akagi, S. K., Toohey, D. W., and Wold, C. E.: Trace gas and particle emissions from open biomass burning in Mexico, Atmos. Chem. Phys. Discuss., 11, 7321-7374, doi:10.5194/acpd-11-7321-2011, 2011.

Zängl, G., Chimani, B., and Häberli, C.: Numerical Simulations of the Foehn in the Rhine Valley on 24 October 1999 (MAP IOP 10), Mon. Weather Rev., 132, 368-389, 2004. 